OPEN ACCESS

Edited by:

Alison Buchan,

University of Tennessee, USA

Reviewed by:

Markus V. Lindh,

University of Hawaii at Manoa,

Sweden

Andrew Decker Steen,

University of Tennessee, USA

*Correspondence: Katy Hoffmann

khoffman@mpi-bremen.de

Specialty section:

This article was submitted to

Aquatic Microbiology,

a section of the journal

Frontiers in Microbiology

Received: 03 November 2016 Accepted: 07 February 2017

Published: 24 February 2017

Citation:

Hoffmann $K$, Hassenrück $C$, Salman-Carvalho V, Holtappels $M$ and Bienhold C (2017) Response of Bacterial Communities to Different Detritus Compositions in Arctic

Deep-Sea Sediments.

Front. Microbiol. 8:266.

doi: 10.3389/fmicb.2017.00266

\section{Response of Bacterial Communities to Different Detritus Compositions in Arctic Deep-Sea Sediments}

\author{
Katy Hoffmann ${ }^{1,2 *}$, Christiane Hassenrück ${ }^{1}$, Verena Salman-Carvalho ${ }^{1,2}$, \\ Moritz Holtappels ${ }^{3}$ and Christina Bienhold ${ }^{1,2}$
}

${ }^{1}$ HGF-MPG Joint Research Group for Deep Sea Ecology and Technology, Max Planck Institute for Marine Microbiology, Bremen, Germany, ${ }^{2}$ Biosciences, HGF-MPG Joint Research Group for Deep Sea Ecology and Technology, Alfred-Wegener-Institut Helmholtz-Zentrum für Polar- und Meeresforschung, Bremerhaven, Germany, ${ }^{3}$ Biosciences, Bentho-Pelagic Processes, Alfred-Wegener-Institut Helmholtz-Zentrum für Polar- und Meeresforschung, Bremerhaven, Germany

Benthic deep-sea communities are largely dependent on particle flux from surface waters. In the Arctic Ocean, environmental changes occur more rapidly than in other ocean regions, and have major effects on the export of organic matter to the deep sea. Because bacteria constitute the majority of deep-sea benthic biomass and influence global element cycles, it is important to better understand how changes in organic matter input will affect bacterial communities at the Arctic seafloor. In a multidisciplinary ex situ experiment, benthic bacterial deep-sea communities from the Long-Term Ecological Research Observatory HAUSGARTEN were supplemented with different types of habitat-related detritus (chitin, Arctic algae) and incubated for 23 days under in situ conditions. Chitin addition caused strong changes in community activity, while community structure remained similar to unfed control incubations. In contrast, the addition of phytodetritus resulted in strong changes in community composition, accompanied by increased community activity, indicating the need for adaptation in these treatments. High-throughput sequencing of the $16 \mathrm{~S}$ rRNA gene and 16S rRNA revealed distinct taxonomic groups of potentially fastgrowing, opportunistic bacteria in the different detritus treatments. Compared to the unfed control, Colwelliaceae, Psychromonadaceae, and Oceanospirillaceae increased in relative abundance in the chitin treatment, whereas Flavobacteriaceae, Marinilabiaceae, and Pseudoalteromonadaceae increased in the phytodetritus treatments. Hence, these groups may constitute indicator taxa for the different organic matter sources at this study site. In summary, differences in community structure and in the uptake and remineralization of carbon in the different treatments suggest an effect of organic matter quality on bacterial diversity as well as on carbon turnover at the seafloor, an important feedback mechanism to be considered in future climate change scenarios.

Keywords: climate change, surface sediment, food pulse experiment, opportunistic bacteria, 16S Illumina sequencing, Arctic algae

Abbreviations: 16S rDNA, 16S rRNA gene; BCLA, Bacillaria sp.; CHI, chitin; EEA, extracellular enzymatic activity; EHUX, Emiliania huxleyi; LTER, Long-Term Ecological Research Observatory; MARC, Melosira arctica; TWEI, Thalassiosira weissflogii. 


\section{INTRODUCTION}

Deep-sea sediments below $200 \mathrm{~m}$ water depth cover approximately $65 \%$ of the Earth's surface. In this environment, particle flux from surface waters is the main source of energy and carbon to benthic communities, with only $1-5 \%$ of the exported organic material arriving at the seafloor (Klages et al., 2003; Jørgensen and Boetius, 2007). A small fraction (1-2\%) of the arriving carbon is remineralized in surface sediments within a few days, while much of the remainder gets buried, turning the seabed into the globally most important long-term sink for carbon (Jørgensen and Boetius, 2007). Bacterial communities may constitute up to $90 \%$ of total benthic biomass in the deep sea (Rowe, 1991; Pfannkuche, 1992), serving as essential catalysts in carbon and nutrient cycling (Jørgensen and Boetius, 2007). The availability of organic matter has been identified as a major driver structuring deep-sea communities, including bacterial communities (e.g., Zinger et al., 2011; Bienhold et al., 2012, 2016). Assessing the response of bacterial communities to changing carbon input is therefore important to understand matter fluxes in the deep sea, especially in the context of global climate change.

In this regard, the Arctic Ocean plays a prominent role because of the rapid environmental changes occurring in this region. As a consequence of increasing surface water temperatures and seaice retreat, the composition and amount of Arctic phytoplankton and sinking organic matter is currently undergoing major changes (Michel et al., 2006; Arrigo et al., 2008; Bauerfeind et al., 2009). In extreme cases, the sudden, massive export of fresh sea-ice algae to the deep-sea floor in the Central Arctic resulted in local hypoxic conditions beneath such algal patches (Boetius et al., 2013). Despite these changes in the quality and quantity of organic matter exported to the deep-sea benthos, little is known about the effects on benthic community structure and functioning. Therefore, the major objective of this study was to evaluate the response of Arctic benthic bacterial deep-sea communities to different organic matter sources.

Methodologically, the retrieval of deep-sea sediment samples, and the large diversity of benthic bacterial communities are two major challenges in this area of research. In contrast to logistically challenging in situ experiments, ex situ studies (Boetius and Lochte, 1994; Boetius and Damm, 1998; Mayor et al., 2012) allow for comparisons between different treatments under controlled conditions, including sample replication. Previous studies have provided simple nutrient sources to investigate the response of bacterial communities to organic matter input (Jannasch et al., 1973; Jannasch and Wirsen, 1982; Deming and Colwell, 1985). Few have also used more complex food sources, such as chitin and whole algae (Deming, 1985; Moodley et al., 2002; Kanzog et al., 2009), which represent more environmentally relevant sources of organic matter. Results indicated that bacterial communities respond to the deposition of organic matter within a few days, as recorded by increases in the activity of extracellular enzymes, bacterial biomass, and community oxygen consumption (Turley and Lochte, 1990; Witte et al., 2003b). However, only more recent studies included analyses of whole bacterial community structure, or single taxonomic groups by applying fingerprinting methods (Yanagibayashi et al., 1999; Kanzog et al., 2009), cloning, and sanger sequencing (Toffin et al., 2004; Parkes et al., 2009; Gärtner et al., 2011). Other studies that sampled along natural environmental gradients of organic matter availability have identified potential opportunistic groups, e.g., Alteromonadaceae, Psychromonadaceae, and Flavobacteriaceae which were positively related with organic matter availability (Bienhold et al., 2012; Jacob et al., 2013). But, experimental studies still lacked combined measurements of community function and high-resolution taxonomic community structure in response to the addition of natural complex food sources.

Here, we used deep-sea surface sediments from the Arctic Ocean Long-Term Ecological Research Observatory (LTER) HAUSGARTEN located in the Fram Strait (Soltwedel et al., 2015) to perform experimental carbon additions, and monitor the response of benthic bacterial communities. The particulate organic carbon flux at this well-studied site is generally less than $30 \mathrm{mg} \mathrm{C} \mathrm{m}^{-2} \mathrm{~d}^{-1}\left(\sim 1 \mathrm{mg} \mathrm{C} \mathrm{mL}^{-1} \mathrm{yr}^{-1}\right)$ at $200-300 \mathrm{~m}$ water depth, and is mainly composed of fecal pellets, calcium carbonate, refractory particulate organic carbon, and biogenic particulate silica (Bauerfeind et al., 2009; Lalande et al., 2013). Since 2005, strong declines in diatom numbers, such as Thalassiosira weissflogii, have led to shifts in phytoplankton community composition. At the same time, a dominance of coccolithophores, especially Emiliania huxleyi, as well as the prymnesiophyte Phaeocystis was observed in the sinking material (Bauerfeind et al., 2009; Soltwedel et al., 2015), but effects on benthic communities remain unknown.

In this study, deep-sea sediment slurries were amended with different types of organic matter, including four different naturally occurring Arctic algae species, and chitin as the most abundant biopolymer in the oceans, e.g., as a main component of fecal pellets. Incubations were performed at in situ temperature and atmospheric pressure, with parallel in situ pressure incubations as controls. After 23 days, changes in key community functions were assessed along with changes in bacterial taxonomic composition. In contrast to natural environmental gradients that may have persisted over extended periods of time, the present study has a short experimental duration and specifically targets fast-growing bacterial groups. We hypothesized (i) that the input of different particulate organic carbon sources to deep-sea sediments differentially affects microbial degradation rates and growth, (ii) that community structure varies with organic matter types, and (iii) that we can identify rapidly responding, i.e., fast-growing, potentially polymer-degrading bacterial groups, representing an opportunistic part of the sediment microbiome.

\section{MATERIALS AND METHODS}

\section{Sediment Sampling}

Surface sediments were sampled at the central station of the LTER HAUSGARTEN, located in the Fram Strait west of Spitsbergen $\left(79^{\circ} 03.86^{\prime} \mathrm{N}, 4^{\circ} 10.85^{\prime} \mathrm{E} ; 2,470 \mathrm{~m}\right.$ water depth). A TV-guided multiple corer (MUC; Barnett et al., 1984) was used for retrieving undisturbed sediments during RV Polarstern cruise PS93.2 (PS93/050-5 and -6; Soltwedel, 2015). Surface sediments were 
fully oxic (300 $\mu \mathrm{mol} \mathrm{L}^{-1} \mathrm{O}_{2}$ ) and consisted of fine clays (Kanzog et al., 2008). Immediately after sediment retrieval, a control sample 'day 0', representing the in situ bacterial community structure, was taken and frozen at $-80^{\circ} \mathrm{C}$ for RNA and at $-20^{\circ} \mathrm{C}$ for DNA extractions.

For the feeding experiment, the first two centimeters of ten cores were combined into one sterile glass bottle and transferred into a cold room $\left(0^{\circ} \mathrm{C}\right.$, in situ temperature). The sediment was 3.5-fold diluted with sterile-filtered and air saturated bottom water ( $35 \mathrm{PSU} ; 0^{\circ} \mathrm{C}$ ), in order to supply enough oxygen for at least one community duplication. The well-mixed slurry was divided into six sterile $1 \mathrm{~L}$ glass bottles. One bottle with slurry remained as unfed control. The other five bottles were amended with substrates to final concentrations of $0.2 \mathrm{mg}$ organic carbon per $\mathrm{mL}$ undiluted sediment, which corresponds to $16.6 \mathrm{mmol}$ $\mathrm{L}^{-1}$ organic carbon, and is comparable to an annual input of particulate organic carbon at this site (Bauerfeind et al., 2009; Kanzog and Ramette, 2009; Lalande et al., 2013). All treatments were divided into ten replicates of $50 \mathrm{~mL}$ each, transferred and sealed into sterile, gas-permeable polyethylene (PE) bags with no headspace or air bubbles.

\section{Incubation}

Slurry incubations were started within $24 \mathrm{~h}$ after retrieval of the samples, using pressure vessels described in Boetius and Lochte (1994). Ten pressure vessels were filled with fully oxygenated sterile-filtered bottom water, and six PE bags were added to each of them (one replicate bag of each of the five treatments, and one control bag). Five of these pressure vessels were incubated at atmospheric pressure (1 atm), the other five at in situ pressure (250 atm). Pressure was applied as hydrostatic (water) pressure, using a mechanical pump. The PE bag material was oxygen permeable, so that oxygen diffusion into the bags prevented the slurries from becoming anoxic (Supplementary Table S1; Supplementary Data). All incubators were stored at $0^{\circ} \mathrm{C}$ in the dark for 23 days.

\section{Food Sources Used in this Study}

We selected five different, naturally occurring, complex substrates to test functional and structural responses of Arctic deep-sea bacterial communities. These were: chitin (CHI), Thalassiosira weissflogii (TWEI), Emiliania huxleyi (EHUX), Bacillaria sp. (BCLA), and Melosira arctica (MARC).

Chitin is one of the main components of, e.g., fecal pellets, exoskeletons of worms, arthropods, and mollusks, and thus constitutes a key source of carbon and nitrogen to deep-sea life (Wakeham and Lee, 1993). Here, we used a commercially available product (flakes from shrimp shells, Sigma-Aldrich, Germany). As more complex detritus we added different algae: the centric diatom TWEI, representing a major fraction of sinking particulate organic matter at HAUSGARTEN observatory, as well as the coccolithopore EHUX that has been reported to migrate from the Atlantic towards the Arctic (Bauerfeind et al., 2009; Winter et al., 2014). Furthermore, we provided detritus of the sea-ice algae BCLA (Stecher et al., 2015), a pennate diatom, and MARC, a centric diatom. As a consequence of sea-ice melting, these sea-ice algae can cause massive sedimentation events that strongly impact local sediment turnover rates (McMahon et al., 2006; Boetius et al., 2013). In reference to the incubations, the term phytodetritus includes all algae used (EHUX, TWEI, BCLA and MARC), of which EHUX and TWEI belong to phytoplankton, and BCLA and MARC to the sea-ice algae.

\section{Algal Cultivation, Sterilization, and Tests Prior to Usage}

TWEI, EHUX, and BCLA were collected during several Arctic cruises, and were cultivated in F/2-medium (Guillard and Ryther, 1962; Guillard, 1975). Algal mats dominated by MARC (but also containing few other species of pennate diatoms and Chaetoceros sp.) were collected directly from the ice during Polarstern cruise PS86 in July 2014 (Boetius, 2015) and frozen at $-20^{\circ} \mathrm{C}$.

The phytoplankton species (TWEI and EHUX) were incubated in $2.5 \mathrm{~L} \mathrm{~F} / 2$ medium at $18^{\circ} \mathrm{C}$ and $15 \mu \mathrm{E}$ using $5 \mathrm{~L}$ beakers, and were resuspended twice a week by gentle shaking. TWEI and EHUX were transferred into new media every 10 days. $100 \mathrm{~mL}$ of the $2.5 \mathrm{~L}$ culture were used to inoculate fresh medium, while the remainder was centrifuged at $1811 \times \mathrm{g}$, and the pellet was frozen at $-20^{\circ} \mathrm{C}$. BCLA was grown at $0^{\circ} \mathrm{C}$ and $10 \mu \mathrm{E}$ in $400 \mathrm{~mL}$ medium in a $1 \mathrm{~L}$ beaker. Due to slower growth, it was transferred and harvested once a month as described above.

For inactivating algal-attached bacteria, we sterilized the algae with microwave radiation at $600 \mathrm{~W}$ for three minutes before adding them to the slurry. Sterilization may alter organic matter lability, as has been shown for the process of autoclaving (Turley and Lochte, 1990; Wolf and Skipper, 1994). This may, to some extent, cause changes similar to the natural aging of organic matter, but was not quantified in more detail here. This treatment also led to a disintegration and homogenization of the algae cultures. The effective sterilization was tested by measurements of enzyme activity, oxygen uptake, bacterial cell numbers, and bacterial genetic diversity, which were all negative or without significant increase or change. The carbon and nitrogen content of the different food sources were determined according to Grasshoff et al. (1983), using a Fisons element analyzer type NA 1500 (Fisons plc, UK). C:N ratios were 8:1 for CHI, 10:1 for TWEI, 11:1 for EHUX, 12:1 for BCLA and 23:1 for MARC.

\section{Acridine Orange Direct Cell Counts (AODC)}

To determine prokaryotic cell numbers, $1 \mathrm{~mL}$ sediment slurry was fixed with sterile filtered formalin/seawater at a final concentration of $2 \%$ and stored at $4^{\circ} \mathrm{C}$. Each sample was filtered on a $0.2 \mu \mathrm{m}$ polycarbonate filter, stained with acridine orange as DNA dye (0.01\% final concentration), and counted using an epifluorescence microscope (Axiophot II Imaging, Zeiss, Jena, Germany). For each sample, 30 random grids from two replicate filters (technical replicates) of three biological replicates, representing three out of five replicate PE-bags per treatment, were counted (Meyer-Reil, 1983). Bacterial biomass

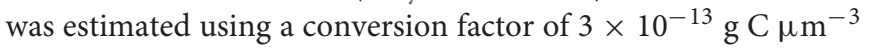


biovolume (Børsheim et al., 1990), and assuming an average cell volume of $0.07 \mu \mathrm{m}^{3}$ (Boetius and Lochte, 1996).

\section{Potential Extracellular Enzymatic Activity (EEA)}

By measuring the potential hydrolytic activity of two abundant enzymes, $\mathrm{N}$-acetylglucosaminidase (chitobiase) and betaglucosidase, in a modification of the method by Hoppe (1983) we tested, which of the supplied macromolecular organic substrates induced a production of extracellular enzymes in the community. Two $11 \mathrm{~mL}$ subsamples were taken from each of the five replicate PE-bags, and mixed with the methylumbelliferon (MUF)-labeled artificial substrates 4-methylumbelliferyl $B$-D-glucopyranoside (MUF-beta-glucosidase) and 4-methylumbelliferyl- $N$-acetyl- $B-D$ glucosaminide (MUF-chitobiase), at saturation levels (100 $\mu \mathrm{mol}$ $\mathrm{L}^{-1}$ ) according to the method described in Boetius and Lochte (1994; Supplementary Table S2). The assay was run at $0^{\circ} \mathrm{C}$ for three hours at atmospheric pressure. We measured the release of the fluorochrome (MUF) after one and three hours, using a RF-5300 spectrofluorophotometer (Shimadzu Scientific, USA; emission: $455 \mathrm{~nm}$, excitation: $365 \mathrm{~nm}$ ). Fluorescent activity was calibrated with MUF standards ranging between 0 and

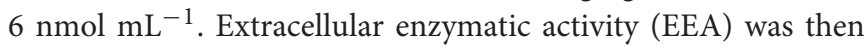
calculated per volume of sediment and time $\left(\mu \mathrm{mol} \mathrm{mL}^{-1} \mathrm{~d}^{-1}\right)$. Since substrate concentrations are at saturation level within the incubation time, enzyme activities represent maximum velocities (Vmax). Enzymatic activity measurements may be confounded by competitive inhibition between the fluorogenic substrate and the added carbon (Arnosti, 2011). However, previous studies have reported an induction of enzyme production for beta-glucosidase and chitobiase by their respective substrates (Boetius and Lochte, 1994; Boetius and Lochte, 1996).

\section{Oxygen Uptake}

Oxygen concentrations were measured at the end of the incubation in each of the five replicate PE-bags per treatment as an indicator of community activity over the duration of the experiment. Optodes were connected to the FireStingO $\mathrm{O}_{2}$ fiber-optic oxygen meter (both obtained from Pyro Science $\mathrm{GmbH}$, Germany), and calibrated at in situ temperatures by a two-point calibration using air-purged seawater and oxygen-free seawater by adding sodiumhydrogensulfite (Sigma Aldrich, Germany). The measuring accuracy was between $0.2 \%$ at $20 \%$ oxygen and $0.01 \%$ at $1 \%$ oxygen (Firesting $\mathrm{O}_{2}$, Fiber-optic Oxygen Meter manual, Pyro Science GmbH, Germany). The PE-bags were gently shaken to mix the slurries and punctured immediately after retrieval from the incubator with the needle-protected optode fiber. Oxygen concentrations were measured in the center of the slurries. Because the PE-bags were oxygen-permeable, the measured oxygen concentration at the end of the 23 days of incubation was in steady state, i.e., the microbial respiration in the bag was balanced by the diffusive transport of oxygen across the PE-foil. From previous tests, an oxygen diffusion coefficient of $2.65 \times 10^{-12} \mathrm{~m}^{-2} \mathrm{~s}^{-1}$ was determined and in combination with the oxygen difference across the PE-foil, the bulk flux and thus the respiration rate in each of the bags were determined (Supplementary Data; Supplementary Table S1; Supplementary Figure S1).

\section{DNA/RNA Extraction and cDNA Generation}

The analysis of 16S rRNA-genes (16S rDNA) reveals all taxa present in a given sample, while the analysis of the 16S rRNA identifies those taxa actively transcribing RNA under a given condition. From the latter, the metabolically active bacterial community can be inferred, and community shifts may be more easily detected (Moeseneder et al., 2005; Gaidos et al., 2011).

For DNA extraction, $7 \mathrm{~mL}$ slurry of three replicate PE-bags per treatment were sampled, centrifuged $(3 \mathrm{~min}$ at $3000 \mathrm{rpm}$ to remove the overlaying water) and stored at $-20^{\circ} \mathrm{C}$. Total DNA was extracted from $0.5 \mathrm{~g}$ sediment with the UltraClean Soil DNA Isolation Kit (MoBio Laboratories Inc., Carlsbad, CA, USA), and quantified using a microplate spectrometer (Infinite ${ }^{\circledR} 200$ PRO NanoQuant, TECAN Ltd, Switzerland). For assessing the active fraction of the bacterial community, $20 \mathrm{~mL}$ slurry of one replicate per treatment were sampled, immediately frozen in liquid nitrogen and stored at $-80^{\circ} \mathrm{C}$. Total RNA was extracted from $5 \mathrm{~g}$ sediment with the MoBio PowerSoil RNA extraction Kit (MoBio Laboratories Inc., Carlsbad, CA, USA). After DNAse digestion and purification using the RNeasy MinElute Cleanup Kit (QIAGEN, Germany), the purity and quantity were determined by electrophoresis using the 2100 Bioanalyzer (Agilent Technologies, Inc., Santa Clara, CA, USA). The extracts were translated into cDNA using the qScriptTM cDNA SuperMix Kit (Quanta Biosciences, Gaithersburg, MD, USA).

\section{Amplicon Sequencing and Sequence Processing}

For 16S cDNA amplicon library preparation, the standard instructions of the $16 \mathrm{~S}$ Metagenomic Sequencing Library Preparation protocol (Illumina, Inc., San Diego, CA, USA) were followed. The hypervariable V3-V4 region of the bacterial $16 \mathrm{~S}$ cDNA and rDNA was sequenced using the bacterial primers S-D-Bact-0341-b-S-17 (5'-CCTACGGGNGGCWGCAG-3') and S-D-Bact-0785-a-A-21 (5'-GACTACHVGGGTATCTAATCC-3'; Klindworth et al., 2013). Sequences were obtained on the Illumina MiSeq platform in a $2 \times 300$ bp paired-end run as well as in a $2 \times 250$ bp paired-end run on the Illumina HiSeq platform (CeBiTec Bielefeld, Germany). Raw paired-end reads were primer-trimmed using cutadapt (Martin, 2011). For quality trimming, a sliding window of four bases and a minimum average quality of 15 was applied in trimmomatic v0.32 (Bolger et al., 2014), and the reads were merged using PEAR v0.9.5 (Zhang et al., 2014). Clustering into OTUs was done with the swarm algorithm using default parameters (v2.0; Mahé et al., 2014). One representative sequence per OTU was taxonomically classified with SINA (SILVA Incremental Aligner; v1.2.11; Silva reference database release 123) at a minimum alignment similarity of 0.9 , and a last common ancestor consensus of 0.7 (Pruesse et al., 
2012). OTUs that were classified as chloroplasts, mitochondria, Archaea, and those not classified at the domain level were excluded from further analyses, as well as OTUs that occurred with only a single sequence in the whole dataset.

\section{Statistical Analysis}

Enzyme activity, cell abundances, and respiration rates based on oxygen measurements were calculated per volume of undiluted sediment. Differences between treatments were calculated based on ANOVA (analysis of variance) with Tukey HSD post hoc tests at a significance threshold of 0.05 (Hothorn et al., 2008). For cell counts, where technical replicates were available, mixed model ANOVA and the implementation of Tukey HSD in the $\mathrm{R}$ package multcomp were used. EEA and AODC data were square-root transformed to meet the assumptions of ANOVA.

Observed richness (number of OTUs) and evenness (inverse Simpson index) of the communities, were calculated via repeated random subsampling to the minimum library size of the amplicon data set (i.e., 26,712 sequences). The change in community structure (beta-diversity) between samples was assessed by calculating Bray-Curtis dissimilarities from relative OTU abundances [\%], to produce non-metric multidimensional scaling (NMDS) plots, and to visualize community similarity between the $16 \mathrm{~S}$ rRNA and rDNA datasets as well as between the different treatments.

The R-package ALDEx2 (ANOVA Like Differential Expression) was used to identify differentially abundant OTUs and families between treatments in the rDNA data set. Only OTUs that were present in two out of three replicates were used for the ALDEx2 analysis. Prior to analysis, proportional $16 \mathrm{~S}$ rDNA based OTU abundances were centered log ratio (clr-) transformed using the aldex.clr function in $\mathrm{R}$ with 128 Dirichlet instances (Fernandes et al., 2014). Taxa were classified as differentially abundant at an adjusted parametric significant threshold of 0.05 (Benjamini and Hochberg, 1995), and at an unadjusted, non-parametric significance threshold of 0.05 . Furthermore, the pairwise average difference and the effect size between the treatments at day 23 compared to the start of the incubation were calculated in the rDNA data set (Fernandes et al., 2014). Taxa were identified as responding to the treatments at an effect size of more than 4 and an average difference between treatments of more than $\log _{2} 2$ or less than $\log _{2} 0.5$, i.e., one duplication or decrease by half in relative abundance. Since only one sample per treatment was available for the rRNA data set, no statistical analyses could be performed. Here, only abundant taxa with a relative sequence abundance of at least $1 \%$ (on OTU level) in at least one sample were screened for responses to the carbon treatments, and only taxa exhibiting at least one duplication or a decrease by half after 23 days are reported. On family level, only differentially abundant taxa with relative sequence abundances above $2 \%$ in at least one sample will be discussed.

All statistical analyses were conducted in $\mathrm{R}$ using the core distribution (version 3.3.0; R Development Core Team, 2014) and the following packages: vegan (Oksanen et al., 2015), ALDEx2 (Fernandes et al., 2014), nlme (Pinheiro et al., 2016), and multcomp (Hothorn et al., 2008).

\section{Data Accession Numbers}

Data are accessible via the Data Publisher for Earth \& Environmental Science PANGAEA ${ }^{1}$ (Hoffmann et al., 2016). Raw paired-end sequence, primer-trimmed reads are available on ENA Accession Number: PRJEB17614. The data were archived using the brokerage service of GFBio (Diepenbroek et al., 2014).

\section{RESULTS}

To assess the response of an Arctic benthic bacterial community to different detritus additions, we determined bacterial cell numbers, estimated biomass, and measured enzymatic activities of two extracellular enzymes, as well as oxygen uptake. Variations in total (16S rDNA) and metabolically active (16S rRNA) bacterial community structure were assessed with $16 \mathrm{~S}$ tag sequencing of the V3-V4 region. The observed effects represent net community changes, as sediments were unsieved, allowing for bacterial grazing by, e.g., protists, and viral pressure. All data presented below are based on incubations conducted at atmospheric pressure (1 atm). General patterns were comparable between incubations at atmospheric and in situ pressure conditions at $250 \mathrm{~atm}$. Corresponding results are shown in the Supplementary Material (Supplementary Figures S2-S6 and Supplementary Tables S3 and S4). We present here comparisons between the initial sediment community at day 0 and the community incubated for 23 days with or without (unfed control) carbon amendments, if not stated otherwise.

\section{Cell Biomass}

Prokaryotic cell numbers in sediments retrieved from the central HAUSGARTEN station were on average $1.4 \pm 0.2 \times 10^{9}$ cells $(\mathrm{mL} \text { sediment })^{-1}(n=3)$. After 23 days of incubation, cell numbers increased in all treatments, and in the unfed control, with highest cell numbers of about $4 \times 10^{9}$ cells $\mathrm{mL}^{-1}$ in the CHI treatment (ANOVA, $F_{1,9}=152.7, p<0.05$ ) (Figure 1A; Table 1). Accordingly, bacteria in CHI treatments showed the highest estimated assimilation of carbon into biomass, i.e., $17 \%$ of the supplied carbon, while bacteria assimilated around $8 \%$ of the supplied carbon in MARC treatments, and $\leq 5 \%$ in the remaining algae treatments (Table 1). Based on the cell numbers, estimated duplication times ranged between 33 days for the control incubation and 12 days for the CHI-treated samples. The unfed control may serve as an approximation of community doubling times in Arctic deep-sea surface sediments, which can thus be estimated to about four weeks. The corresponding biomass calculations represent rough estimates of carbon conversion into bacterial biomass, as we did not quantitatively determine changes in cell volumes.

\section{Enzymatic Activity}

Chitobiase and beta-glucosidase enzymatic activities increased significantly in all carbon-amended samples, while enzymatic activities in the unfed control remained low (approximately $0.01 \mu \mathrm{mol} \mathrm{mL} \mathrm{m}^{-1} \mathrm{~d}^{-1}$ ), and were close to starting conditions

\footnotetext{
${ }^{1}$ https://doi.org/10.1594/PANGAEA.867475
} 
A

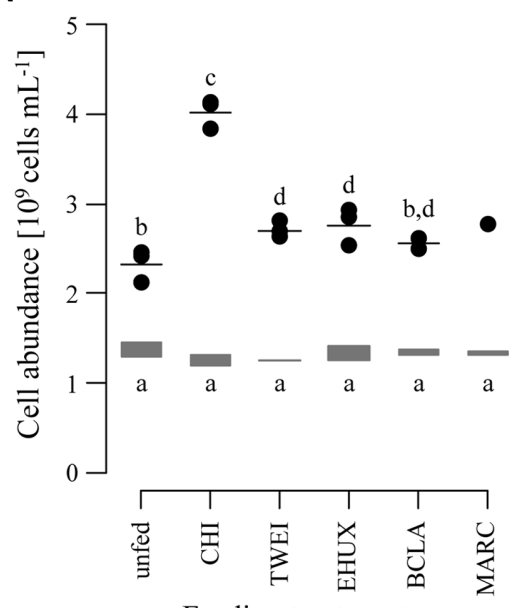

Feeding treatment

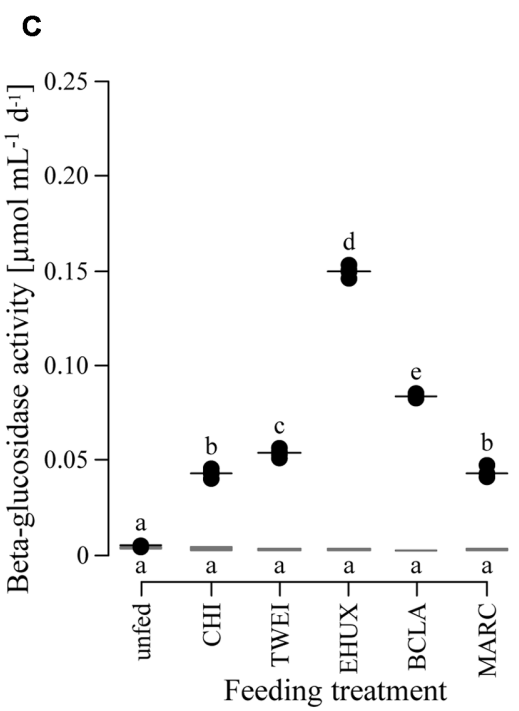

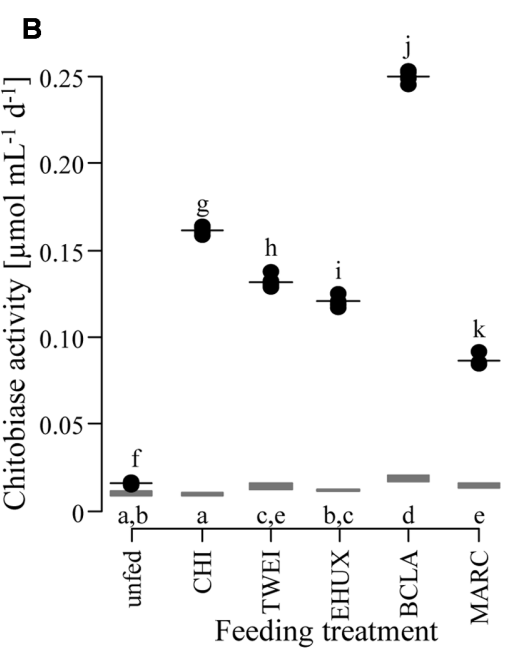

D

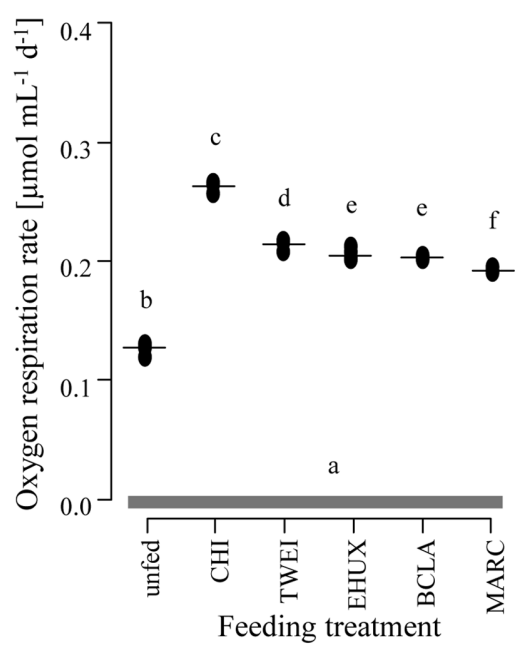

FIGURE 1 | Changes in cell abundance $(\mathbf{A} ; n=3)$, extracellular enzyme activity (B: chitobiase, $\mathbf{C}$ : beta-glucosidase; $n=5)$, and oxygen respiration rates $(\mathbf{D}$; $n=5$ ) of the sediment community in the different treatments under atmospheric pressure conditions. Gray bars show the range at the beginning of the incubation. Black dots show measurements after 23 days of incubation, with the horizontal black line indicating the mean value per treatment. Lower case letters indicate groups of treatments that are significantly different from each other based on Tukey HSD at a significance threshold of $p<0.05$. Day 0: starting conditions, unfed: control sediments after 23 days of incubation, carbon amendments: chitin (CHI), Thalassiosira weissflogii (TWEI), Emiliania huxleyi (EHUX), Bacillaria sp. (BCLA), Melosira arctica (MARC). Only one measurement of cell abundance was available for MARC-treated sediment.

(chitobiase: ANOVA, $F_{11,48}=5,811, p<0.05$; beta-glucosidase: ANOVA, $F_{11,48}=5,297, p<0.05$; Figures 1B,C). Highest chitobiase activity was measured in the BCLA-fed sediments with $0.25 \mu \mathrm{mol} \mathrm{mL} \mathrm{m}^{-1} \mathrm{~d}^{-1}$, which was 16-fold higher than in the unfed control, followed by CHI amended samples with $0.16 \mu \mathrm{mol} \mathrm{mL} \mathrm{m}^{-1} \mathrm{~d}^{-1}$. The remaining algaefed communities showed a moderate increase in chitobiase activity $\left(0.10-0.13 \mu \mathrm{mol} \mathrm{mL} \mathrm{m}^{-1} \mathrm{~d}^{-1}\right)$. All carbon treatments were significantly different from the unfed control and from each other (Tukey HSD, $p<0.05$; Figure 1B). Highest betaglucosidase activity was induced in the EHUX treatments with $0.15 \mu \mathrm{mol} \mathrm{mL} \mathrm{m}^{-1} \mathrm{~d}^{-1}$, which represents a 30 -fold higher activity compared to the unfed control. Lowest beta-glucosidase activity was induced in the $\mathrm{CHI}$ and MARC treatments, turning over only $0.04 \mu \mathrm{mol} \mathrm{mL} \mathrm{m}^{-1} \mathrm{~d}^{-1}$. TWEI and BCLA addition resulted in moderate beta-glucosidase activities. All carbon treatments were significantly different from the unfed control and from each other (Tukey HSD, $p<0.05$; Figure 1C), except for beta-glucosidase activity in the $\mathrm{CHI}$ and MARC treatments. Calculation of the total hydrolysis potential of both measured enzymes over the duration of the experiment showed that communities in BCLA and EHUX treatments had the highest potentials (52 and $38 \mu \mathrm{mol} \mathrm{C} \mathrm{mL} \mathrm{m}^{-1} \mathrm{~d}^{-1}$, respectively), whereas MARC treatments had the lowest $\left(17 \mu \mathrm{mol} \mathrm{C} \mathrm{mL} \mathrm{L}^{-1} \mathrm{~d}^{-1}\right)$. 


\section{Oxygen Uptake}

Over the 23 days of incubation, oxygen concentrations declined significantly in all treatments (ANOVA, $F_{6,28}=3,381, p<0.05$; Figure 1D; Table 1). Inferred oxygen uptake among the treated sediment slurries ranged between $6.1 \mu \mathrm{mol} \mathrm{O}_{2} \mathrm{~mL}^{-1}$ and $4.4 \mu \mathrm{mol} \mathrm{O}_{2} \mathrm{~mL}^{-1}$ sediment over 23 days for $\mathrm{CHI}$ and MARC treatments, respectively (Table 1 ). The unfed control showed lowest oxygen uptake of $2.9 \mu \mathrm{mol} \mathrm{O}_{2} \mathrm{~mL}^{-1}$ sediment in 23 days. Based on the calculated oxygen uptake, 19 and $9 \%$ of the added carbon have been respired at the end of the incubation period for CHI and MARC treatments, respectively (Figure 1D; Table 1). Oxygen uptake calculated for the addition of the planktonic algae and BCLA were equally moderate, with approximately $10 \%$ of the added carbon being respired (Table 1).

\section{Bacterial Diversity and Community Structure (16S rDNA and rRNA) \\ General Trends}

In total, 32,502-277,806 rDNA and 26,712-125,131 rRNA reads were generated per sample, corresponding to $1,731-12,549$, and 3,012-16,384 swarmed, non-singleton OTUs, respectively. Changes in community structure were assessed separately for the $16 \mathrm{~S} \mathrm{rDNA}$ and rRNA sequence datasets, and samples from the two different approaches had an average intra-sample Bray-Curtis dissimilarity of $30 \%$ on family level, and $50 \%$ on OTU level. However, overall variations in community structure between treatments were significantly correlated between $16 \mathrm{~S}$ rDNA and rRNA data on OTU and family level (Figure 2; Mantel test based on Bray-Curtis dissimilarity, $r=0.7, p<0.05$ for both taxonomic levels). Also, variations in community structure were highly correlated between experiments at atmospheric and at in situ pressure of $250 \mathrm{~atm}$ (Mantel test based on Bray-Curtis dissimilarity, $r=0.9, p<0.05$ on OTU and family level for rRNA and rDNA). Because data from biological replicates were available, we mainly focus on rDNA results under atmospheric pressure conditions here. Differences in the trends between rDNA and rRNA datasets are explicitly mentioned.

Bacterial communities were most diverse at the start of the incubation, with an observed bacterial richness of 5,777 OTUs and an inverse Simpson diversity index of 359 (Table 2). Diversity decreased significantly after 23 days in all treatments (OTU number: ANOVA, $F_{6,13}=136.8, p<0.05$; inverse Simpson index: ANOVA, $F_{6,13}=345.3, p<0.05$; Table 2 ), but not in control sediments. After 23 days of incubation, effective species richness was highest in the unfed samples with an inverse Simpson index of 193, followed by the CHI treatments with 56 . Phytodetritus treatments resulted in the lowest alpha-diversity, with inverse Simpson indices ranging between 25 and 38 .

The sediment community at the start of the incubation was dominated by Proteobacteria, comprising more than $60 \%$ of $16 \mathrm{~S}$ rDNA sequences, and by members of the Bacteroidetes, Planctomycetes, Chloroflexi, and Acidobacteria, all of which showed relative sequence abundances between 5 and 10\% (Figure 3). An NMDS plot based on Bray-Curtis dissimilarity revealed three distinct groups of samples at a $70 \%$ dissimilarity threshold (Figure 2). Bacterial community structure in the unfed control on day 23 was still very similar to the initial bacterial community. CHI treatments grouped separately, but were still similar to the unfed treatments. Phytodetritus treatments formed a third group, which was clearly separated from the unfed control and $\mathrm{CHI}$ treatments (Figure 2).

Overall, 30 bacterial families of eight different phyla had a relative sequence abundance, i.e., sequence proportion $>2 \%$ in at least one sample, and were identified as differentially abundant on rDNA level (Figure 4). About one third of these differentially abundant families (12 families), which were mainly affiliated with Gamma- and Deltaproteobacteria, and Bacteroidetes, increased significantly during incubations, whereas the other two thirds (18 families) decreased. The 12 families, which increased most strongly in relative sequence abundance in the different treatments, were identified as key responding, opportunistic bacterial families. These included four families responding to all treatments, including the unfed control: Colwelliaceae, Moritellaceae, Psychromonadaceae, and Shewanellaceae. In addition, four families responded to all carbon amendments: Desulfuromonadaceae, unclassified Desulfuromonadales and Alteromonadales families, as well as Campylobacteraceae. Another three families showed a strong positive response in relative sequence abundance especially to the supply of phytodetritus: Flavobacteriaceae, Geobacteraceae, and Marinilabiaceae. The Oceanospirillaceae increased significantly in the unfed control treatment, on average sixfold stronger than in any other treatment except for the CHI sample. Furthermore, minor changes in the unfed control treatment included an increase in relative sequence abundance of four gammaproteobacterial families, and a slight decrease of two families belonging to the Chloroflexi and Acidobacteria. Otherwise, no changes in the majority of the most abundant families were detected (Figure 4). In total, the 12 opportunistic families increased from 3\% relative sequence abundance at the beginning of the incubation to on average $89 \%$ in carbon treatments after 23 days of incubation (Supplementary Tables $\mathrm{S} 4 \mathrm{~A}, \mathrm{~B})$. The only case of pronounced differences between rDNA and rRNA results was the unfed control after 23 days. On the level of active transcription (rRNA), diverse families belonging to the phylum Acidobacteria, i.e., subgroups 6, 10, 26 (unclassified), NS72, and SVA0725, as well as the alphaproteobacterial family Sphingomonadaceae increased strongly in relative sequence abundance. This was not the case on rDNA level, which still closely resembled the starting community composition.

\section{Chitin Treatments}

Overall, a different set of families responded to the $\mathrm{CHI}$ treatment compared to the phytodetritus treatments. CHI treatment led to a significant increase in nine out of the 30 differentially abundant families, whereas three decreased compared to the initial sediment community. In contrast to phytodetritus treatments, Colwelliaceae, Psychromonadaceae, and Oceanospirillaceae were most strongly affected by $\mathrm{CHI}$ treatments, increasing from $<1 \%$ of $16 \mathrm{~S}$ rDNA relative sequence abundance to 25,12 , and $8 \%$, respectively (Figure 4; Supplementary Table S4A). Overall, most bacterial families with higher relative sequence abundances in the unfed controls, e.g., Oceanospirillaceae, or in phytodetritus 


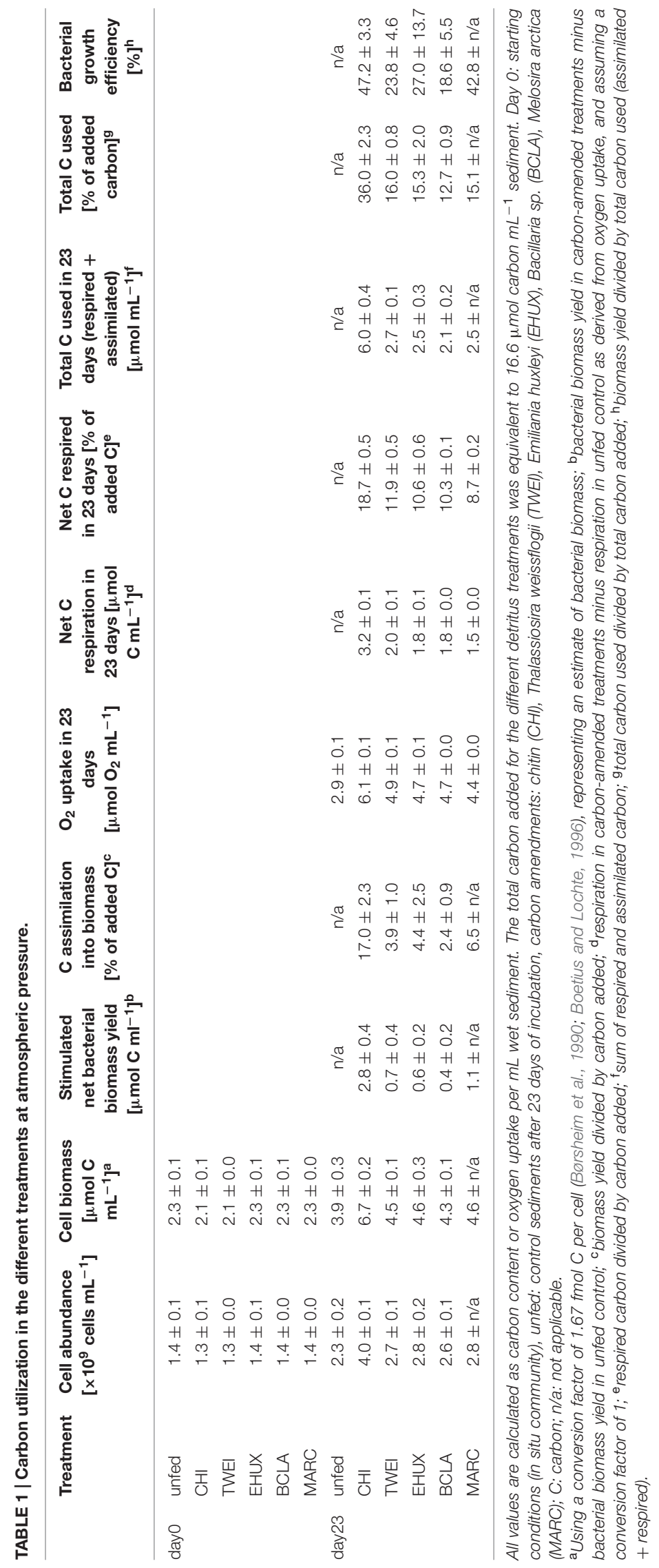




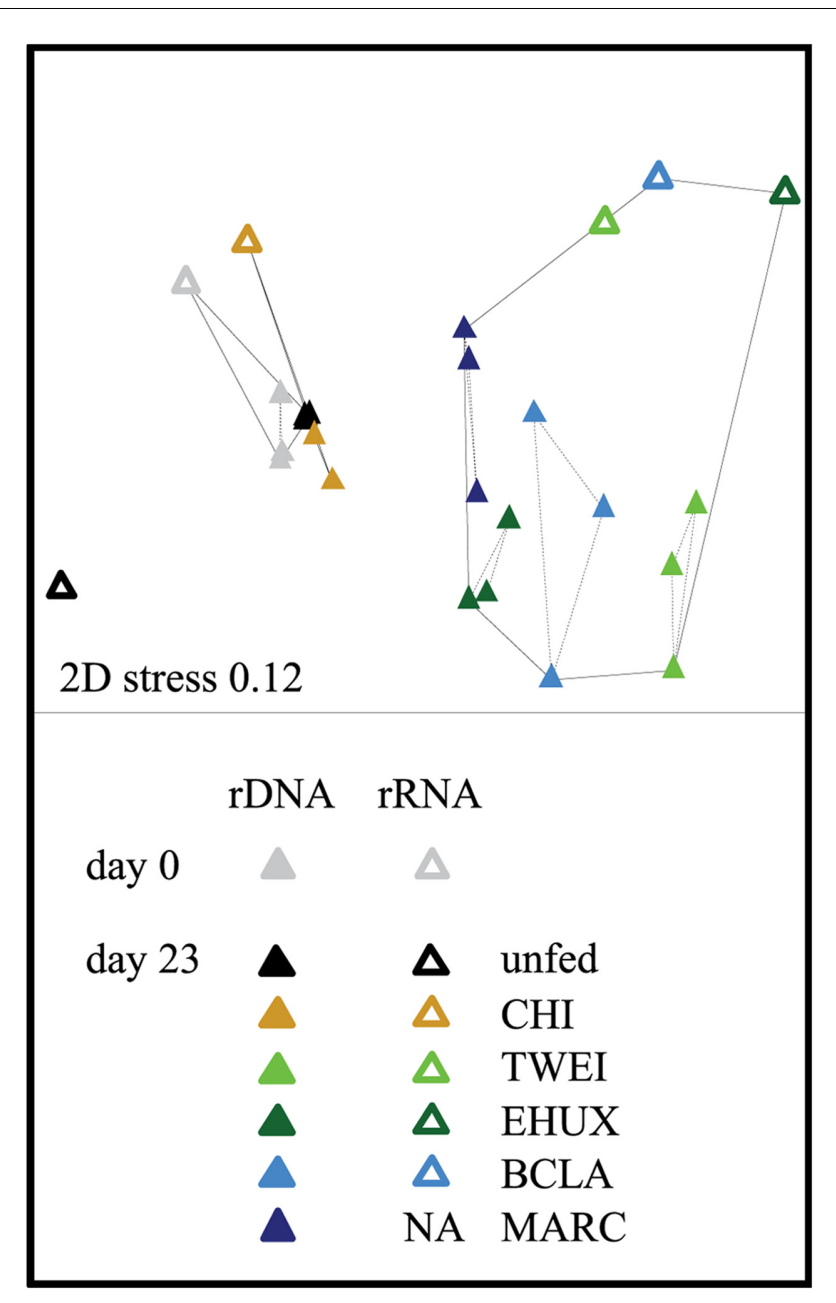

FIGURE 2 | Non-metric multidimensional scaling (NMDS) plot based on Bray-Curtis dissimilarity of the total (16S rDNA; $n=3$ ) and active (16S rRNA; $n=1$ ) bacterial community in the different sediment treatments under atmospheric pressure conditions. Hulls displayed by solid lines are based on a dissimilarity threshold of $70 \%$. Hulls displayed by dashed lines are based on a dissimilarity threshold of $32 \%$, and shows clusters of biological replicates. Day 0: starting conditions, unfed: control sediments after 23 days of incubation, carbon amendments: chitin $(\mathrm{CHI})$, Thalassiosira weissflogii (TWEI), Emiliania huxleyi (EHUX), Bacillaria sp. (BCLA), Melosira arctica (MARC). No rRNA data is available for MARC-treated sediment.

treatments, e.g., Campylobacteraceae and Desulfuromonadaceae, also increased in relative abundance in $\mathrm{CHI}$ treatments (Figure 4).

\section{Phytodetritus Treatments}

All phytodetritus treatments led to stronger changes in community structure than observed for unfed controls and CHI treatments after 23 days of incubation (Figure 2). On average, eleven families increased and 15 decreased in relative sequence abundance in phytodetritus treatments, and they were very similar in their phylogenetic affiliation across all treatments (Figure 4; Supplementary Table S4A). The families most strongly increasing in relative sequence abundance for the different algal treatments were Flavobacteriaceae, Moritellaceae, and Desulfobacteraceae for TWEI, Marinilabiaceae, unclassified Desulfuromonadales families, and Geobacteraceae for TWEI as well as EHUX, and an unclassified group of Alteromonadales for EHUX. Desulfuromonadaceae, Shewanellaceae, and Campylobacteraceae responded strongest to BCLA. All of the abundant families classified as opportunistic in algal treatments (EHUX, TWEI, BCLA) also increased significantly in MARC treatments.

\section{Response of Bacterial Groups at High Taxonomic Resolution}

The analysis of differentially abundant bacterial groups at a higher taxonomic resolution, i.e., at OTU level, revealed intra-genus differences in their response to the different treatments in four out of the 30 differentially abundant families. Within the genera Arcobacter (Campylobacteraceae), Colwellia (Colwelliaceae), Moritella (Moritellaceae) and Psychromonas (Psychromonadaceae), several OTUs displayed opposing trends among the treatments, in addition to the overall pattern observed at lower taxonomic resolution (SI text).

\section{DISCUSSION}

Environmental changes in the Arctic Ocean lead to changes in the quality and quantity of organic matter exported from surface waters to the deep sea (McMahon et al., 2006; Bauerfeind et al., 2009; Boetius et al., 2013), but little is known about the effects on benthic community structure and function. In this study, we aimed at evaluating the response of benthic bacterial communities of the Arctic deep-sea floor to different organic matter sources in short-term, ex situ experiments. Using an experimental setup allowing for approximately one community duplication (Table 1), we were able to observe changes in community functions and, for the first time, identified bacterial groups that responded within days to the addition of different naturally occurring organic matter sources, i.e., chitin and different species of algae.

Responses in growth, extracellular enzymatic activities, and oxygen uptake were observed for all organic matter treatments compared to unfed control incubations after 23 days. This showed that bacterial communities actively responded to the input of organic matter by initiating degradation of the organic matter and producing biomass. This observation is supported by previous studies from various deep-sea environments (Deming, 1985; Turley and Lochte, 1990; Boetius and Lochte, 1994, 1996; Witte et al., 2003a). Although carbon uptake appeared to be slightly lower for incubations under in situ pressure (see also: Jannasch, 1979; Jannasch and Wirsen, 1982), oxygen consumption was higher, resulting in hypoxic conditions after 23 days. Despite this discrepancy, similar results were obtained for incubations at atmospheric and in situ pressure (Figures 1-4; Supplementary Figures S2-S6), of which the latter need to be interpreted with caution, as we cannot clearly distinguish between the effects of pressure and oxygen depletion in the high-pressure treatments. 
TABLE 2 | Alpha diversity indices of the bacterial community in the incubation experiment.

\begin{tabular}{|c|c|c|c|c|c|}
\hline & \multirow[b]{2}{*}{ Treatment } & \multicolumn{2}{|c|}{ nOTUs } & \multicolumn{2}{|c|}{ invS } \\
\hline & & Value & Tukey HSD & Value & Tukey HSD \\
\hline \multicolumn{6}{|l|}{ rDNA } \\
\hline & day0 & $5,777 \pm 56$ & a & $359 \pm 28$ & a \\
\hline & unfed & $5,113 \pm 54$ & $\mathrm{a}$ & $193 \pm 22$ & $b$ \\
\hline & $\mathrm{CHI}$ & $3,479 \pm 359$ & $b$ & $56 \pm 8$ & C \\
\hline & TWEI & $1,323 \pm 95$ & C & $26 \pm 0$ & d \\
\hline & EHUX & $1,786 \pm 44$ & $d$ & $25 \pm 10$ & $d$ \\
\hline & BCLA & $1,686 \pm 286$ & d & $35 \pm 1$ & e \\
\hline & MARC & $1,922 \pm 131$ & d & $38 \pm 2$ & e \\
\hline \multicolumn{6}{|l|}{ rRNA } \\
\hline & day0 & 7,816 & NA & 1,230 & NA \\
\hline & unfed & 2,767 & NA & 45 & NA \\
\hline & $\mathrm{CHI}$ & 4,602 & NA & 67 & NA \\
\hline & TWEI & 2,362 & NA & 32 & NA \\
\hline & EHUX & 2,358 & NA & 34 & NA \\
\hline & BCLA & 2,498 & NA & 34 & NA \\
\hline & MARC & NA & NA & NA & NA \\
\hline
\end{tabular}

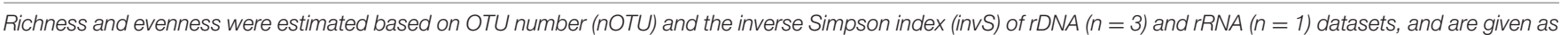

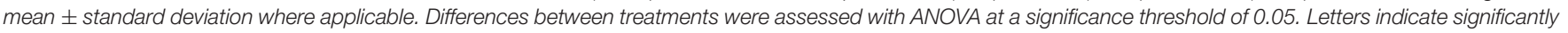

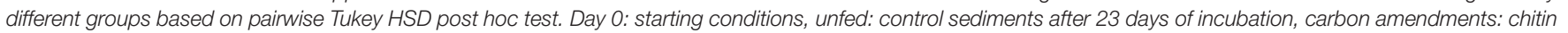
$(\mathrm{CHI})$, Thalassiosira weissflogii (TWEI), Emiliania huxleyi (EHUX), Bacillaria sp. (BCLA), Melosira arctica (MARC).

A

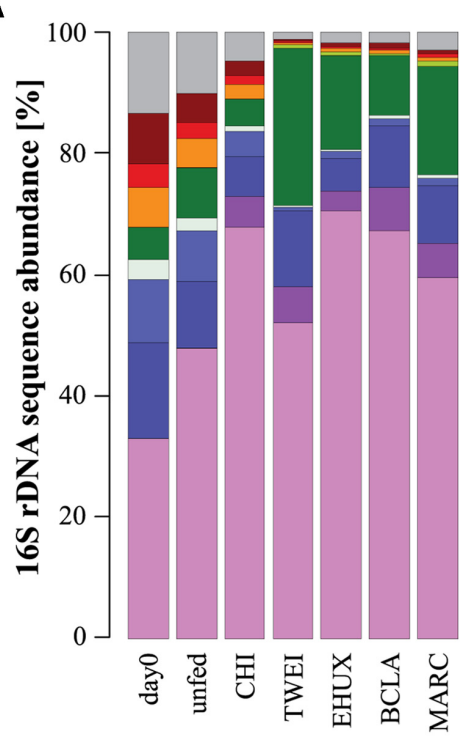

B

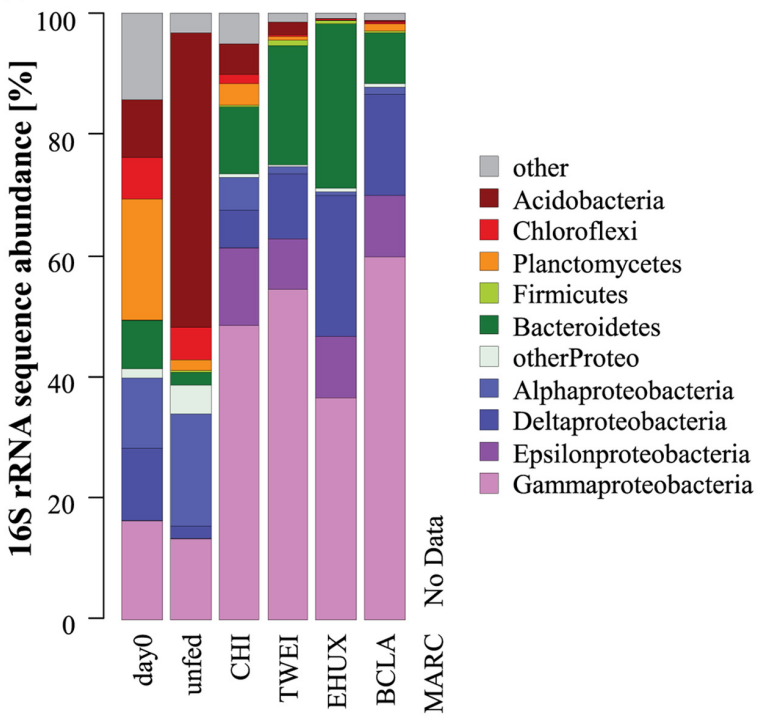

FIGURE 3 | Dominant phyla of the total (A: 16S rDNA; $n=3)$ and active (B: 16S rRNA; $n=1)$ bacterial community in the different sediment treatments under atmospheric pressure conditions. For the total bacterial community, sequences from replicate samples were pooled for the calculation of relative sequence abundances. For Proteobacteria, class-level resolution is shown. Day 0: starting conditions, unfed: control sediments after 23 days of incubation, carbon amendments: chitin (CHI), Thalassiosira weissflogii (TWEI), Emiliania huxleyi (EHUX), Bacillaria sp. (BCLA), Melosira arctica (MARC).

In addition to the response in bulk growth and activity measurements, we observed clear shifts in diversity (Table 2) and community structure (Figure 2) as a result of organic matter additions. The responding taxa were generally consistent between rDNA and rRNA, indicating that shifts in bacterial community structure quickly translated from a higher activity (rRNA) to cell replication (rDNA). Furthermore, changes in community structure were largely consistent between incubations at 1 and $250 \mathrm{~atm}$, indicating that most of the opportunistic bacterial groups appear to cope well with de-/re-compression for the investigated water depth $(2,500 \mathrm{~m})$. Accordingly, pressure effects have repeatedly been hypothesized to be negligible below 

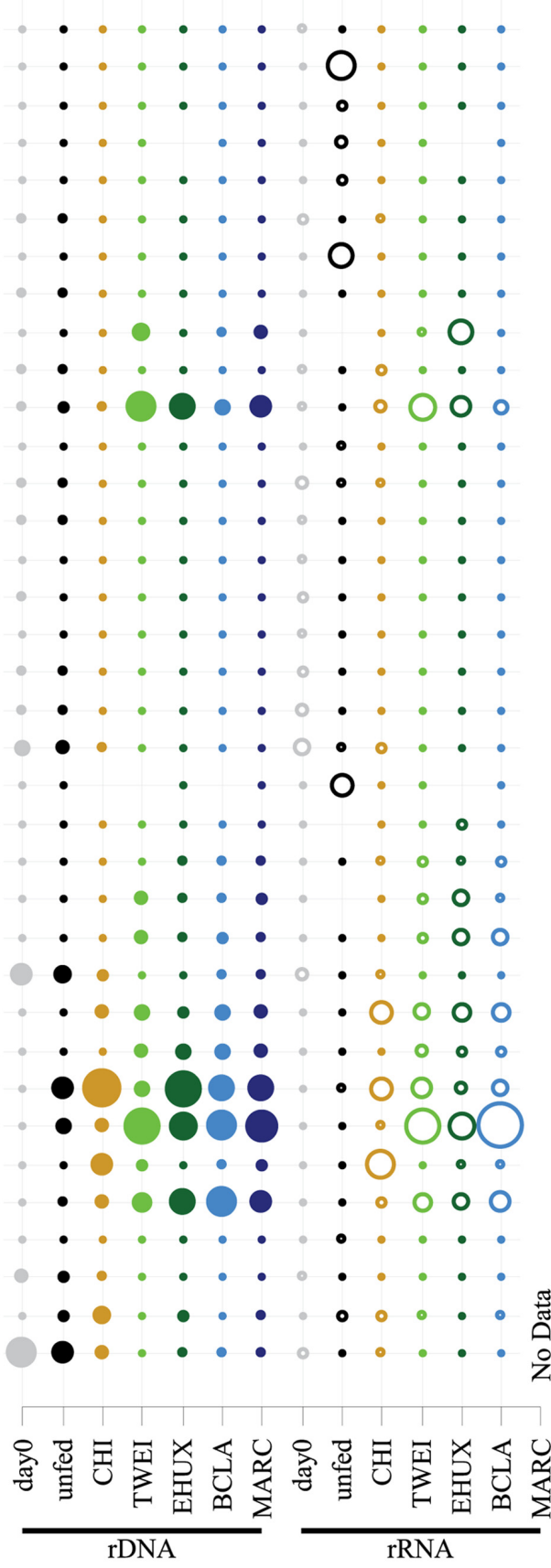

PAUC26f

Subgroup 6 (uncl.) *

NS72 *

Subgroup 10 (uncl.)

Sva0725*

Subgroup 22 (uncl.) *

Subgroup 26 (uncl.)

OM1 clade *

Marinilabiaceae *

Flammeovirgaceae *

Flavobacteriaceae *

Anaerolineaceae *

SAR202 clade (uncl.) *

BD2-11 terrestrial group (uncl.) *

Hydrogenedentes (uncl.) *

OM190 (uncl.) *

CCM11a (uncl.)

Phycisphaeraceae *

Planctomycetaceae *

Rhodospirillaceae *

Sphingomonadaceae

Desulfobacteraceae *

Desulfuromonadaceae *

Desulfuromonadales (uncl.) *

Geobacteraceae *

Sh765B-TzT-29 (uncl.) *

Campylobacteraceae *

Alteromonadales (uncl.) *

Colwelliaceae *

Moritellaceae *

Psychromonadaceae *

Shewanellaceae *

Arenicellaceae

BD7-8 marine group (uncl.) *

䒕 - Oceanospirillaceae *

JTB255 marine benthic group *
Acidobacteria

Actinobacteria

Bacteroidetes

Chloroflexi

Gemmatimonadetes

|Hydrogenedentes

Planctomycetes

Alphaproteobacteria

Deltaproteobacteria

|Epsilonproteobacteria

$\mid$
Gammaproteobacteria

FIGURE 4 | Dot plot showing relative sequence abundances of dominant bacterial families, and their phylum affiliation, of the total (16S rDNA; $n=3$ ) and active (16S rRNA; $n=1)$ bacterial community in the different sediment treatments under atmospheric pressure conditions. For the total bacterial community, sequences from replicate samples were pooled for the calculation of relative sequence abundances. For families of the Proteobacteria, class-level resolution is shown. For taxa that were unclassified at the respective level of resolution, the next higher taxonomic rank is shown. Asterisks mark differentially abundant taxa between treatments based on 16S rDNA samples (ALDEx2 analysis). All groups that are not marked by an asterisk were only abundant in 16S rRNA data, for which no replicates are available and therefore no analysis of differential abundance could be performed. Day 0: starting conditions, unfed: control sediments after 23 days of incubation, carbon amendments: chitin (CHI), Thalassiosira weissflogii (TWEI), Emiliania huxleyi (EHUX), Bacillaria sp. (BCLA), Melosira arctica (MARC). No rRNA data is available for MARC-treated sediment.

approximately 200-300 atm (Yayanos, 1986; Follonier et al., 2012; Picard and Daniel, 2013). Obligate piezophilic bacteria mainly derive from below 6,000 $\mathrm{m}$ water depth (Yayanos,
1986), and most bacterial groups from shallower water depths are described to be rather piezotolerant (Picard and Daniel, 2013). 


\section{Changes in the Untreated Control Community}

For both, atmospheric and in situ pressure incubations, an increase in bacterial biomass in control treatments indicated that the presence of sedimentary organic carbon provided sufficient energy for an increase of the bacterial standing stock. This may be partly due to the onset of a settling phytoplankton bloom in the area during the time of sampling (Soltwedel, 2015), but also to the presence of refractory organic material. The initial (in situ) sediment bacterial community (Figure 3) was very similar to previous reports from this site (Jacob et al., 2013), and from other deep-sea surface sediments globally (Zinger et al., 2011; Bienhold et al., 2016; Learman et al., 2016). OTUs affiliating with the gammaproteobacterial families Oceanospirillaceae and Colwelliaceae showed a strong increase in relative sequence abundance in the unfed control treatments after 23 days of incubation, but also in CHI treatments. These groups are known to include polymer degraders (Methé et al., 2005; Weiner et al., 2008). Additionally, the genera Colwellia and Marinomonas sp. (Oceanospirillaceae) have been reported to produce polyhydroxyalkanoate compounds, which serve as intracellular carbon and energy reserves (Methé et al., 2005; Cai et al., 2011). This may be a beneficial strategy for organisms living in organic-poor sediments of the Arctic deep sea.

We also observed a conspicuous increase in relative rRNA sequence abundance of deep-branching acidobacterial groups and taxa belonging to the Sphingomonadaceae in the unfed controls after 23 days of incubation. We speculate that the increased relative rRNA sequence abundance may represent a strategy, where in lack of nutrients, energy is invested in maintaining the metabolism rather than increasing biomass (Morita, 1982; Watson et al., 1998 and references therein). However, this pattern was not reproducible in incubations at $250 \mathrm{~atm}$, and it remains unknown what caused this discrepancy. Due to the lack of fresh organic material in control incubations, bacteria adapted to more oligotrophic conditions and the breakdown of refractory, aged organic material may become more important. Indeed, Sphingomonadaceae are described to play important roles in oligotrophic environments, and in the degradation of recalcitrant polyaromatic compounds (Ohta et al., 2004; García-Romero et al., 2016). In spite of their frequently observed oligotrophic character, members of this family are widespread in nature, occurring in soils, freshwater, and marine habitats (Cavicchioli et al., 1999; Yabuuchi and Kosako, 2005; Vaz-Moreira et al., 2011). Acidobacteria have also been reported to cope well with low organic matter availability (Fierer et al., 2007; Bienhold et al., 2012). These groups may thus be representatives of a background community, surviving in the oligotrophic conditions that prevail at the deep Arctic seafloor for most of the year.

\section{Effect of Detritus-Type on Bacterial Community Structure and Function}

Chitin addition caused strong functional changes in the sediment microbial community, i.e., the largest increase in net biomass (highest bacterial growth efficiency), highest oxygen consumption rates, and a strong increase in chitobiase activity (Figure 1; Table 1). Despite these effects, and even though overall diversity decreased significantly (Table 2), community composition remained very similar to its initial structure and to control incubations (Figure 2; Supplementary Figure S4). The sediment community thus seemed to be well adapted to the degradation of this type of polymeric organic matter. Since chitin is the most abundant biopolymer in the ocean (Gooday, 1990), and bacteria are the main decomposers of this material in the deep-sea benthos (Christiansen and Boetius, 2000; Kanzog et al., 2009), benthic communities may constantly be exposed to relatively high levels of chitin, and our results may therefore reflect an inherent adaptation to the degradation of this carbon source. The decrease in community diversity probably reflects the loss of taxa that were overgrown by chitin degraders.

In contrast to $\mathrm{CHI}$ treatments, the addition of algae caused a much more moderate response in bulk community function, including lower estimated bacterial growth efficiencies. This is in line with reports by Mayor et al. (2012), who showed that benthic bacteria displayed lower growth efficiencies when respiring diatoms compared to fecal pellet material, and confirms that resource quality may influence carbon uptake and retention potential in natural settings.

There are several potential explanations for the lower bacterial growth efficiencies in algae treatments. Some of the tested algae may contain compounds that suppress growth of certain bacterial groups (Guedes et al., 2011; Qin et al., 2013). As one example, the production of dimethylsulphopropionate (DMSP)related substances by EHUX has been suggested to act as protection against grazers (Hansen et al., 1996; Fileman et al., 2002), and may also inhibit bacterial attachment (Saha et al., 2012). Viral lysis might act as another structuring factor (Proctor and Fuhrman, 1990; Fuhrman and Noble, 1995), as viruses are also considered to be favored by high energy input and biological productivity (Cochlan et al., 1993; Bratbak et al., 1994). Furthermore, meiofauna, e.g., nematodes, may be direct or indirect beneficiaries of the fresh phytodetritus, by either feeding on the algae or on the bacteria (Guilini et al., 2010; Ingels et al., 2010). Numerous studies have shown that fauna may be rapid consumers of fresh phytodetritus at the seafloor (e.g., Blair et al., 1996; Moodley et al., 2002, 2005, Witte et al., 2003a), in particular in the Arctic, following the deposition of ice algae or phytoplankton (McMahon et al., 2006; Morata et al., 2011, 2015). To further resolve the substrate degradation cascade, labeled substrates could be used in future experiments (Witte et al., 2003a,b; Guilini et al., 2010).

Compared to CHI treatments, we observed a much stronger decrease in bacterial diversity as well as shifts in community structure in all phytodetritus treatments, indicating the response of a few adapted groups outcompeting others. This suggests that changes in community composition needed to precede changes in community function (Schindler, 1987; Niederlehner and Cairns, 1994). This may be due to the fact that the input of relatively fresh algae used in this study is less common than the ubiquitously available chitin. Also, while chitin is solely composed of $N$-acetyl-glucosamine subunits, and only a small set of enzymes is necessary to degrade it, the degradation of algae 
is more complex, involving a cascade of multiple enzymes and bacterial groups (Xing et al., 2015; Teeling et al., 2016).

Changes in community structure and function were very similar between the phytoplankton (TWEI, EHUX) and sea-ice algae (BCLA, MARC) treatments, despite presumable differences in their nutritional value (McMahon et al., 2006; Sun et al., 2007). However, the input dynamics of these organic matter sources in the natural system would differ profoundly. Specifically, a slow rain of phytoplankton cells that are already being degraded on their way through the water column represent a stark contrast to a highly concentrated and localized input of large ice algae aggregates sinking rapidly to the deep seafloor. These scenarios would likely result in differential impacts on community structure, functioning, and carbon turnover.

\section{Taxon-Specific Responses to Carbon Amendments}

Previous studies have already identified links between organic matter quantity and bacterial community structure in marine sediments (Franco et al., 2007; Bienhold et al., 2012; Learman et al., 2016). Here, we specifically addressed the response of bacterial communities to different types of organic matter when provided in a single, large pulse. Overall, we identified 12 bacterial families on both rRNA and rDNA level that increased in relative sequence abundance in the organic matter treatments, and that were consistent between incubations under atmospheric and in situ pressure conditions. These opportunistic bacterial groups may represent the specific community fraction that contributed to the increase in enzyme activity, biomass, and oxygen respiration, and that might thus be of key importance for initial polymer degradation at the deep-sea floor. The gammaproteobacterial families Colwelliaceae, Psychromonadaceae, and Oceanospirillaceae were found in highest abundances in CHI treated sediments. Gammaproteobacteria are a globally ubiquitous group in marine environments that have been described as versatile opportunists and copiotrophs (Glöckner et al., 1999; Bienhold et al., 2012). Indeed, representatives of the family Oceanospirillaceae, e.g., the genera Marinomonas and Neptunomonas, have been described to degrade chitin (Nogi et al., 2004; González and Whitman, 2006; Jung, 2006). Also representatives of the families Colwelliaceae and Psychromonadaceae appear to have a broad substrate spectrum including complex organic compounds (Methé et al., 2005; Auman et al., 2006). Several members of the Colwelliaceae have been reported to hydrolyze chitin (Huston et al., 2000, 2004; Ivanova et al., 2004). We therefore identify these bacterial groups as potential opportunists, especially in scenarios of high chitin input, such as mass sedimentation events of crustaceans (Sokolova, 1994; Christiansen and Boetius, 2000).

For Psychromonadaceae, only some species are described as being able to degrade chitin (e.g., strain Psychromonas ingrahamii 37; Riley et al., 2008), whereas other species, e.g., Psychromonas arctica, appear to lack this ability (Groudieva et al., 2003). This supports our findings of a strong increase in relative sequence abundance for diverse OTUs affiliated with Psychromonas in CHI amended slurries on the one hand, and a decrease of other Psychromonas-associated OTUs on the other hand, which instead showed a stronger response in algae treatments (SI text). This deviation is consistent with previous reports for this genus in a similar environment (Bienhold et al., 2012), and demonstrates the usefulness of community information at a high taxonomic resolution. In the future, genomic and physiological studies may reveal in more detail the different metabolic niches that these taxa occupy.

Several other families were identified with most pronounced shifts in the algae treatments. Flavobacteria from Arctic sediments were recently described to exhibit a strong positive correlation with energy availability (Bienhold et al., 2012), consistent with the association of copiotrophy to the phylum Bacteroidetes (Fierer et al., 2007). Also, Flavobacteria and Alteromonadales, in particular Pseudoalteromonadales, have shown strong responses to phytoplankton blooms (Teeling et al., 2016; Xing et al., 2015). Representatives of the order Pseudoalteromonadales, e.g., Pseudoalteromonas haloplanktis, which shares closest sequence identity to the responsive clade in our study, can produce anti-biofilm molecules (Parrilli et al., 2016). It may be able to degrade extracellular polymeric substances produced by phytoplankton and ice algae like MARC by using its diverse set of enzymes, including peptidases, amylase, and alpha-glucosidase (Médigue et al., 2005). In the future, extended monitoring periods after the addition of organic matter, combined with metagenomic and metatranscriptomic approaches, may yield further insights into succession patterns, species competition, and niche adaptation, e.g., as observed for bacterial communities associated with phytoplankton blooms in the water column (Teeling et al., 2012).

Most of the opportunistic bacterial groups identified in this study contain psychrophilic and psychrotolerant cultured representatives (Médigue et al., 2005; Methé et al., 2005; Auman et al., 2006; Riley et al., 2008; Lee et al., 2012) with mostly heterotrophic lifestyles (e.g., Médigue et al., 2005; Methé et al., 2005), the potential for motility (e.g., Médigue et al., 2005; Auman et al., 2006; Lee et al., 2012), and biofilm formation (e.g., Médigue et al., 2005; Methé et al., 2005; Riley et al., 2008; Baek et al., 2015). The latter two features may aid the association with, and directed degradation of particulate organic matter in the deep sea (O'Toole et al., 2000; Golyshin et al., 2002), but the relevance of such mechanisms remains speculative and will require further investigations. Most of the groups are not specific or exclusive for the sediment environment, but cover a wide range of natural habitats, and appear to have a rather cosmopolitan character (e.g., Médigue et al., 2005; Methé et al., 2005; Zhao et al., 2005; Auman et al., 2006; Xing et al., 2015). Nevertheless, many of the closely related cultured representatives were isolated from polar marine environments, and are described to produce coldadapted enzymes, capable of degrading high-molecular-weight organic compounds, e.g., Alteromonadales (Médigue et al., 2005), Colwelliaceae (Methé et al., 2005), Shewanellaceae (Zhao et al., 2010), Psychromonadaceae (Riley et al., 2008), Moritellaceae (Lee et al., 2012; Malecki et al., 2013), Flavobacteriaceae (Pati et al., 2011; Baek et al., 2015; Xing et al., 2015), and Oceanospirillaceae (Weiner et al., 2008). Future research may therefore identify explicit Arctic and/or sediment ecotypes within these groups, which need to be further metabolically characterized 
using genomic and physiological methods, in order to assess their role in the turnover of organic matter in Arctic marine sediments.

\section{CONCLUSION}

The observed differences in community structure, carbon uptake, and remineralization between the treatments suggest that changes in the type of organic matter exported to the seafloor will have consequences for bacterial diversity and carbon turnover. The families Colwelliaceae, Psychromonadaceae, and Oceanospirillaceae may represent indicator groups for $\mathrm{CHI}$ input, and Flavobacteriaceae, Pseudoalteromonadaceae, and Marinilabiaceae for phytodetritus input in this Arctic region. However, quantitative methods targeting specific groups of interest, such as Catalyzed Reporter Deposition-Fluorescence In Situ Hybridization (CARD-FISH) and quantitative PCR, are needed to confirm the changes observed in the compositional sequencing datasets, and to further link taxonomic groups (at high taxonomic resolution) to specific community functions. Furthermore, the metabolic potential of these key responding groups remains to be investigated to better understand their role in ecosystem functioning. Future studies should combine ex situ and in situ observations at extended time periods. Experimental approaches will be helpful in order to monitor changes and succession patterns in community structure and function after disturbances. Additionally, longterm environmental observations are needed to better assess the effects of shifts in organic matter quality and quantity on ecosystem functioning in the context of seasonal variations and spanning several years.

\section{AUTHOR CONTRIBUTIONS}

$\mathrm{KH}$ and $\mathrm{CB}$ designed experiments. $\mathrm{KH}$ performed the experiments. $\mathrm{KH}, \mathrm{CH}$, and $\mathrm{CB}$ analyzed data, and VS-C assisted in data interpretation. $\mathrm{MH}$ performed oxygen sensor data analysis and modeling. $\mathrm{KH}, \mathrm{VS}-\mathrm{C}$, and $\mathrm{CB}$ wrote the manuscript with support and input from all co-authors. All authors critically revised the article and gave their approval of the submitted version.

\section{REFERENCES}

Arnosti, C. (2011). Microbial extracellular enzymes and the marine carbon cycle. Ann. Rev. Mar. Sci. 3, 401-425. doi: 10.1146/annurev-marine-120709-142731

Arrigo, K. R., van Dijken, G., and Pabi, S. (2008). Impact of a shrinking Arctic ice cover on marine primary production. Geophys. Res. Lett. 35, 1-6. doi: 10.1029/ 2008GL035028

Auman, A. J., Breeze, J. L., Gosink, J. J., Kämpfer, P., and Staley, J. T. (2006). Psychromonas ingrahamii sp. nov., a novel gas vacuolate, psychrophilic bacterium isolated from Arctic polar sea ice. Int. J. Syst. Evol. Microbiol. 56, 1001-1007. doi: 10.1099/ijs.0.64068-0

Baek, K., Lee, Y. M., Hwang, C. Y., Park, H., Jung, Y. J., Kim, M. K., et al. (2015). Psychroserpens jangbogonensis sp. nov., a psychrophilic bacterium isolated from Antarctic marine sediment. Int. J. Syst. Evol. Microbiol. 65, 183-188. doi: 10. 1099/ijs.0.069740-0

\section{FUNDING}

Funding was provided by the ERC Advanced Investigator Grant ABYSS (294757) to Antje Boetius. Additional funding came from the Helmholtz Association and the Max Planck Society. This publication is Eprint ID 42060 of the Alfred-Wegener-Institut Helmholtz Zentrum für Polar- und Meeresforschung, Bremerhaven, Germany.

\section{ACKNOWLEDGMENTS}

We greatly thank the captain and crew of RV Polarstern expedition PS93.2 (ARK29.2) as well as the chief scientist Thomas Soltwedel. Thank you very much to Paul Wassmann for hosting us for post-cruise experiments in his laboratories at the University of Tromsø, Norway in August 2015. We are further thankful to Josephine Z. Rapp, Axel Nordhausen and Gerdhard Jessen Reyes for assistance in sampling, and to Jakob Barz and Susanne Menger for their fantastic help with sample processing. Many thanks are due to Halina Tegetmeyer for intensive sequencing efforts, as well as Gunter Wegener and Frank Wenzhöfer for helpful discussions on calculations. Thank you to Anya Waite, Anique Stecher and Erika Allhusen, for sharing their algal starting cultures. We also thank the German Federation for Biological Data (GFBio), in particular Ivaylo Kostadinov, Marc Weber and Janine Felden for their support in long-term data archiving. Thanks goes to Sebastian Wolf for constructive and stimulating discussions. We are greatly indebted to Antje Boetius for constructive comments and helpful discussions about the content of this study. We further thank the editor and two reviewers for their helpful comments on the manuscript.

\section{SUPPLEMENTARY MATERIAL}

The Supplementary Material for this article can be found online at: http://journal.frontiersin.org/article/10.3389/fmicb. 2017.00266/full\#supplementary-material

Barnett, P. R. O., Watson, J., Connelly, D., and Marine, D. (1984). A multiple corer for taking virtually undisturbed samples from shelf, bathyal and abyssal sediments. Oceanol. Acta 7, 399-408.

Bauerfeind, E., Nöthig, E. M., Beszczynska, A., Fahl, K., Kaleschke, L., Kreker, K., et al. (2009). Particle sedimentation patterns in the eastern Fram Strait during 2000-2005: results from the Arctic long-term observatory HAUSGARTEN. Deep Res. Part I Oceanogr. Res. Pap. 56, 1471-1487. doi: 10.1016/j.dsr.2009. 04.011

Benjamini, Y., and Hochberg, Y. (1995). Controlling the false discovery rate: a practical and powerful approach to multiple testing. J. $R$. Stat. Soc. Series B Stat. Methodol. 57, 289-300. doi: 10.2307/234 6101

Bienhold, C., Boetius, A., and Ramette, A. (2012). The energy-diversity relationship of complex bacterial communities in Arctic deep-sea sediments. ISME J. 6, 724-732. doi: 10.1038/ismej.2011.140 
Bienhold, C., Zinger, L., Boetius, A., and Ramette, A. (2016). Diversity and biogeography of bathyal and abyssal seafloor bacteria. PLOS ONE 11:e0148016. doi: 10.1371/journal.pone.0148016

Blair, N. E., Levin, L. A., Demaster, D. J., and Plaia, G. (1996). The short-term fate of fresh algal carbon in continental slope sediments. Limnol. Oceanogr. 41, 1208-1219. doi: 10.4319/lo.1996.41.6.1208

Boetius, A. (2015). The Expedition PS86 of the Research Vessel POLARSTERN to the Arctic Ocean in 2014. Reports on Polar and Marine Research (Bremerhaven: Alfred Wegener Institute for Polar and Marine Research). doi: 10.2312/BzPM 0685_2015

Boetius, A., Albrecht, S., Bakker, K., Bienhold, C., Felden, J., FernándezMéndez, M., et al. (2013). Export of algal biomass from the melting Arctic sea ice. Science 339, 1430-1432. doi: 10.1126/science.1231346

Boetius, A., and Damm, E. (1998). Benthic oxygen uptake, hydrolytic potentials and microbial biomass at the Arctic continental slope. Deep Sea Res. Part I Oceanogr. Res. Pap. 45, 239-275. doi: 10.1016/S0967-0637(97)00052-6

Boetius, A., and Lochte, K. (1994). Regulation of microbial enzymatic degradation of organic-matter in deep-sea sediments. Mar. Ecol. Ser. 104, 299-307. doi: 10.3354/meps104299

Boetius, A., and Lochte, K. (1996). Effect of organic enrichments on hydrolytic potentials and growth of bacteria in deep-sea sediments. Mar. Ecol. Prog. Ser. 140, 239-250. doi: 10.3354/meps 140239

Bolger, A. M., Lohse, M., and Usadel, B. (2014). Trimmomatic: a flexible trimmer for Illumina sequence data. Bioinformatics 30, 2114-2120. doi: 10. 1093/bioinformatics/btu170

Børsheim, K. Y., Bratbak, G., and Heldal, M. (1990). Enumeration and biomass estimation of planktonic bacteria and viruses by transmission electron microscopy. Appl. Environ. Microbiol. 56, 352-356.

Bratbak, G., Thingstad, F., and Heldal, M. (1994). Viruses and the microbial loop. Microb. Ecol. 28, 209-221. doi: 10.1007/BF00166811

Cai, L., Tan, D., Aibaidula, G., Dong, X., Chen, J., Tian, W., et al. (2011). Comparative genomics study of polyhydroxyalkanoates (PHA) and ectoine relevant genes from Halomonas sp. TD01 revealed extensive horizontal gene transfer events and co-evolutionary relationships. Microb. Cell Fact. 10, 1-15. doi: 10.1186/1475-2859-10-88

Cavicchioli, R., Fegatella, F., Ostrowski, M., Eguchi, M., and Gottschal, J. (1999). Sphingomonads from marine environments. J. Ind. Microbiol. Biotechnol. 23, 268-272. doi: 10.1038/sj.jim.2900732

Christiansen, B., and Boetius, A. (2000). Mass sedimentation of the swimming crab Charybdis smithii (Crustacea: Decapoda) in the deep Arabian Sea. Deep Sea Res. Part II Top. Stud. Oceanogr. 47, 2673-2685. doi: 10.1016/S0967-0645(00) 00044-8

Cochlan, W. P., Wikner, J., Steward, G. F., and Smith, D. C. (1993). Spatial distribution of viruses, bacteria and chlorophyll a in neritic, oceanic and estuarine environments. Mar. Ecol. Prog. Ser. 92, 77-87.

Deming, J. (1985). Bacterial growth in deep-sea sediment trap and boxcore samples. Mar. Ecol. Prog. Ser. 25, 305-312. doi: 10.3354/meps025305

Deming, J. W., and Colwell, R. R. (1985). Observations of barophilic microbial activity in samples of sediment and intercepted particulates from the demerara abyssal plain. Appl. Environ. Microbiol. 50, 1002-1006.

Diepenbroek, M., Glöckner, F. O., Grobe, P., Güntsch, A., Huber, R., König-Ries, B., et al. (2014). "Towards an integrated biodiversity and ecological research data management and archiving platform: the German federation for the curation of biological data (GFBio)," in Informatik 2014 - Big Data Komplexität meistern. GI-Edition: Lecture Notes in Informatics (LNI) - Proceedings 232, eds E. Plödereder, L. Grunske, E. Schneider, and D. Ull (Bonn: Köllen Verlag), 1711-1724.

Fernandes, A. D., Reid, J. N., Macklaim, J. M., McMurrough, T. A., Edgell, D. R., and Gloor, G. B. (2014). Unifying the analysis of high-throughput sequencing datasets: characterizing RNA-seq, 16S rRNA gene sequencing and selective growth experiments by compositional data analysis. Microbiome 2:15. doi: 10 . 1186/2049-2618-2-15

Fierer, N., Bradford, M. A., and Jackson, R. B. (2007). Toward an ecological classification of soil bacteria. Ecology 88, 1354-1364. doi: 10.1890/05-1839

Fileman, E. S., Cummings, D. G., and Llewellyn, C. A. (2002). Microplankton community structure and the impact of microzooplankton grazing during an Emiliania huxleyi bloom, off the Devon coast. J. Mar. Biol. Assoc. U.K. 82, 359-368. doi: 10.1017/S0025315402005593
Follonier, S., Panke, S., and Zinn, M. (2012). Pressure to kill or pressure to boost: a review on the various effects and applications of hydrostatic pressure in bacterial biotechnology. Appl. Microbiol. Biotechnol. 93, 1805-1815. doi: 10. 1007/s00253-011-3854-6

Franco, M. A., De Mesel, I., Demba Diallo, M., Van Der Gucht, K., Van Gansbeke, D., Van Rijswijk, P., et al. (2007). Effect of phytoplankton bloom deposition on benthic bacterial communities in two contrasting sediments in the southern North Sea. Aquat. Microb. Ecol. 48, 241-254. doi: 10.3354/ ame048241

Fuhrman, J. A., and Noble, R. T. (1995). Viruses and protists cause similar bacterial mortality in coastal seawater. Limnol. Oceanogr. 40, 1236-1242. doi: 10.4319/lo. 1995.40.7.1236

Gaidos, E., Rusch, A., and Ilardo, M. (2011). Ribosomal tag pyrosequencing of DNA and RNA from benthic coral reef microbiota: community spatial structure, rare members and nitrogen-cycling guilds. Environ. Microbiol. 13, 1138-1152. doi: 10.1111/j.1462-2920.2010.02392.x

García-Romero, I., Pérez-Pulido, A. J., González-Flores, Y. E., Reyes-Ramírez, F., Santero, E., and Floriano, B. (2016). Genomic analysis of the nitrate-respiring Sphingopyxis granuli (formerly Sphingomonas macrogoltabida) strain TFA. BMC Genomics 17:93. doi: 10.1186/s12864-016-2411-1

Gärtner, A., Blümel, M., Wiese, J., and Imhoff, J. F. (2011). Isolation and characterisation of bacteria from the Eastern Mediterranean deep sea. Antonie van Leeuwenhoek 100, 421-435. doi: 10.1007/s10482-011-9599-5

Glöckner, F. O., Fuchs, B. M., Fuchs, B. M., Glo, F. O., and Amann, R. (1999). Bacterioplankton compositions of lakes and oceans: a first comparison based on fluorescence in situ hybridization. Appl. Environ. Microbiol. 65, 3721-3726.

Golyshin, P. N., Chernikova, T. N., Abraham, W. R., Lünsdorf, H., Timmis, K. N., and Yakimov, M. M. (2002). Oleiphilaceae fam. nov., to include Oleiphilus messinensis gen. nov., sp. nov., a novel marine bacterium that obligately utilizes hydrocarbons. Int. J. Syst. Evol. Microbiol. 52, 901-911. doi: 10.1099/ijs.0. 01890-0

González, J., and Whitman, W. (2006). Oceanospirillum and related genera. Prokaryotes 6, 887-915. doi: 10.1007/0-387-30746-x

Gooday, G. W. (1990). "The ecology of chitin degradation," in Advances in Microbial Ecology, ed. K. C. Marshall (New York, NY: Plenum Press), 387-430. doi: 10.1007/978-1-4684-7612-5_10

Grasshoff, K., Ehrhardt, M., Kremling, K., and Almgren, T. (eds) (1983). Methods of Seawater Analysis, 2nd Edn. Weinheim: Verlag Chemie.

Groudieva, T., Grote, R., and Antranikian, G. (2003). Psychromonas arctica sp. nov., a novel psychrotolerant, biofilm-forming bacterium isolated from Spitzbergen. Int. J. Syst. Evol. Microbiol. 53, 539-545. doi: 10.1099/ijs.0.02 182-0

Guedes, A. C., Amaro, H. M., and Malcata, F. X. (2011). Microalgae as sources of high added-value compounds-a brief review of recent work. Biotechnol. Prog. 27, 597-613. doi: 10.1002/btpr.575

Guilini, K., Van Oevelen, D., Soetaert, K., Middelburg, J. J., and Vanreusel, A. (2010). Nutritional importance of benthic bacteria for deep-sea nematodes from the Arctic ice margin: results of an isotope tracer experiment. Limnol. Oceanogr. 55, 1977-1989. doi: 10.4319/lo.2010.55.5.1977

Guillard, R. R. L. (1975). "Culture of phytoplankton for feeding marine invertebrates," in Culture of Phytoplankton for Feeding Marine Invertebrates, eds W. L. Smith and M. H. Chanley (New York, NY: Plenum Press), 29-60. doi: 10.1007/978-1-4615-8714-9_3

Guillard, R. R. L., and Ryther, J. H. (1962). Studies of marine planktonic diatoms: I. Cyclotella nana hustedt, and Detonula confervacea (cleve) gran. Can. J. Microbiol. 8, 229-239. doi: 10.1139/m62-029

Hansen, F. C., Witte, H. J., and Passarge, J. (1996). Grazing in the heterotrophic dinoflagellate Oxyrrhis marina: size selectivity and preference for calcified Emiliania huxleyi cells. Aquat. Microb. Ecol. 10, 307-313. doi: 10.3354/ ame010307

Hoffmann, K., Hassenrück, C., Salman-Carvalho, V., Holtappels, M., and Bienhold, C. (2016). Response of Arctic benthic bacterial deep-sea communities to different detritus composition during an ex-situ high pressure experiment. doi: 10.1594/PANGAEA.867475, Supplement to: Hoffmann, K., et al. (2017). Response of bacterial communities to different detritus compositions in Arctic deep-sea sediments. Front. Microbiol. 8:266. doi: 10.3389/fmicb.2017. 00266 
Hoppe, H.-G. (1983). Significance of exoenzymatic activities in the ecology of brackish water: measurements by means of methylumbelliferyl-substrates. Mar. Ecol. Prog. Ser. 11, 299-308. doi: 10.3354/meps011299

Hothorn, T., Bretz, F., Westfall, P., and Heiberger, R. M. (2008). Simultaneous inference in general parametric models. Biom. J. 50, 346-363. doi: 10.1002/bimj. 200810425

Huston, A. L., Krieger-Brockett, B. B., and Deming, J. W. (2000). Remarkably low temperature optima for extracellular enzyme activity from Arctic bacteria and sea ice. Environ. Microbiol. 2, 383-388. doi: 10.1046/j.1462-2920.2000.00118.x

Huston, A. L., Methe, B., Deming, J. W., and Icrobiol, A. P. P. L. E. N. M. (2004). Purification, characterization, and sequencing of an extracellular cold-active aminopeptidase produced by marine psychrophile Colwellia psychrerythraea strain 34H. Appl. Environ. Microbiol. 70, 3321-3328. doi: 10.1128/AEM.70.6. 3321

Ingels, J., Van Den Driessche, P., De Mesel, I., Vanhove, S., Moens, T., and Vanreusel, A. (2010). Preferred use of bacteria over phytoplankton by deep-sea nematodes in polar regions. Mar. Ecol. Prog. Ser. 406, 121-133. doi: 10.3354/ meps08535

Ivanova, E. P., Flavier, S., and Christen, R. (2004). Phylogenetic relationships among marine Alteromonas-like proteobacteria: emended description of the family Alteromonadaceae and proposal of Pseudoalteromonadaceae fam. nov., Colwelliaceae fam. nov., Shewanellaceae fam. nov., Moritellaceae fam. nov., Ferri. Int. J. Syst. Evol. Microbiol. 54, 1773-1788. doi: 10.1099/ijs.0.02997-0

Jacob, M., Soltwedel, T., Boetius, A., and Ramette, A. (2013). Biogeography of Deep-sea benthic bacteria at regional scale (LTER HAUSGARTEN, Fram Strait, Arctic). PLoS ONE 8:e72779. doi: 10.1371/journal.pone.0072779

Jannasch, H. W. (1979). "Microbial ecology of aquatic low nutrient habitats," in Strategies of Microbial Life in Extreme Environments, ed. M. Shilo (Weinheim: Verlag Chemie), 243-260. doi: 10.1002/iroh.19810660215

Jannasch, H. W., and Wirsen, C. O. (1982). Microbial activities in undecompressed and decompressed deep-seawater samples. Appl. Environ. Microbiol. 43, 1116-1124.

Jannasch, H. W., Wirsen, C. O., and Winget, C. L. (1973). A bacteriological pressure-retaining deep-sea sampler and culture vessel. Deep Sea Res. Oceanogr. Abstr. 20, 661-662. doi: 10.1016/0011-7471(73)90033-8

Jørgensen, B. B., and Boetius, A. (2007). Feast and famine-microbial life in the deep-sea bed. Nat. Rev. Microbiol. 5, 770-781. doi: 10.1038/nrmicro1745

Jung, S.-Y. (2006). Colwellia aestuarii sp. nov., isolated from a tidal flat sediment in Korea. Int. J. Syst. Evol. Microbiol. 56, 33-37. doi: 10.1099/ijs.0. 63920-0

Kanzog, C., and Ramette, A. (2009). Microbial colonisation of artificial and deepsea sediments in the Arctic Ocean. Mar. Ecol. 30, 391-404. doi: 10.1111/j.14390485.2009.00290.x

Kanzog, C., Ramette, A., Quéric, N. V., and Klages, M. (2008). Response of benthic microbial communities to chitin enrichment: an in situ study in the deep Arctic Ocean. Polar Biol. 32, 105-112. doi: 10.1007/s00300-008-0510-4

Kanzog, C., Ramette, A., Quéric, N. V., and Klages, M. (2009). Response of benthic microbial communities to chitin enrichment: an in situ study in the deep Arctic Ocean. Polar Biol. 32, 105-112. doi: 10.1007/s00300-008-0510-4

Klages, M., Boetius, A., Christensen, J. P., Deubel, H., Piepenburg, D., Schewe, I., et al. (2003). "The benthos of Arctic seas and its role for the organic carbon cycle at the seafloor," in The Organic Carbon Cycle in the Arctic Ocean, Vol. 6, eds R. Stein and R. W. MacDonald (Heidelberg: Springer), 139-167. doi: 10.1007/978-3-642-18912-8_6

Klindworth, A., Pruesse, E., Schweer, T., Peplies, J., Quast, C., Horn, M., et al. (2013). Evaluation of general 16S ribosomal RNA gene PCR primers for classical and next-generation sequencing-based diversity studies. Nucleic Acids Res. 41:e1. doi: 10.1093/nar/gks808

Lalande, C., Bauerfeind, E., Nöthig, E.-M., and Beszczynska-Möller, A. (2013). Impact of a warm anomaly on export fluxes of biogenic matter in the eastern Fram Strait. Prog. Oceanogr. 109, 70-77. doi: 10.1016/j.pocean.2012.09.006

Learman, D. R., Henson, M. W., Thrash, J. C., Temperton, B., Brannock, P. M., Santos, S. R., et al. (2016). Biogeochemical and microbial variation across 5500 $\mathrm{km}$ of Antarctic surface sediment implicates organic matter as a driver of benthic community structure. Front. Microbiol. 7:284. doi: 10.3389/fmicb.2016. 00284

Lee, S. G., Koh, H. Y., Lee, J. H., Kang, S. H., and Kim, H. J. (2012). Draft genome sequence of Moritella dasanensis strain ArB 0140, a psychrophilic bacterium isolated from the Arctic Ocean. J. Bacteriol. 194, 5452-5453. doi: 10.1128/JB. 01203-12

Mahé, F., Rognes, T., Quince, C., de Vargas, C., and Dunthorn, M. (2014). Swarm: robust and fast clustering method for amplicon-based studies. PeerJ 2:e593. doi: $10.7717 /$ peerj.593

Malecki, P. H., Raczynska, J. E., Vorgias, C. E., and Rypniewski, W. (2013). Structure of a complete four-domain chitinase from Moritella marina, a marine psychrophilic bacterium. Acta Crystallogr. D Biol. Crystallogr. 69, 821-829. doi: 10.1107/S0907444913002011

Martin, M. (2011). Cutadapt removes adapter sequences from high-throughput sequencing reads. EMBnet.journal 17, 10-12. doi: 10.14806/ej.17.1.200

Mayor, D. J., Thornton, B., Hay, S., Zuur, A. F., Nicol, G. W., McWilliam, J. M., et al. (2012). Resource quality affects carbon cycling in deep-sea sediments. ISME J. 6, 1740-1748. doi: 10.1038/ismej.2012.14

McMahon, K. W., Ambrose, W. G. Jr., Johnson, B. J., Sun, M., Lopez, G. R., et al. (2006). Benthic community response to ice algae and phytoplankton in $\mathrm{Ny}$ Ålesund, Svalbard. Mar. Ecol. Prog. Ser. 310, 1-14. doi: 10.3354/meps310001

Médigue, C., Krin, E., Pascal, G., Barbe, V., Bernsel, A., Bertin, P. N., et al. (2005). Coping with cold: the genome of the versatile marine Antarctica bacterium Pseudoalteromonas haloplanktis TAC125. Genome Res. 15, 1325-1335. doi: 10. 1101/gr.4126905

Methé, B. A., Nelson, K. E., Deming, J. W., Momen, B., Melamud, E., Zhang, X., et al. (2005). The psychrophilic lifestyle as revealed by the genome sequence of Colwellia psychrerythraea $34 \mathrm{H}$ through genomic and proteomic analyses. Proc. Natl. Acad. Sci. U.S.A. 102, 10913-10918. doi: 10.1073/pnas.0504766102

Meyer-Reil, L.-A. (1983). Benthic response to sedimentation events during autum to spring at a shallow water station in the Western Kiel Bight. II. Analysis of benthic bacterial populations. Mar. Biol. 77, 247-256. doi: 10.1007/BF00395813

Michel, C., Ingram, R. G., and Harris, L. R. (2006). Variability in oceanographic and ecological processes in the Canadian Arctic Archipelago. Prog. Oceanogr. 71, 379-401. doi: 10.1016/j.pocean.2006.09.006

Moeseneder, M. M., Arrieta, J. M., and Herndl, G. J. (2005). A comparison of DNA- and RNA-based clone libraries from the same marine bacterioplankton community. FEMS Microbiol. Ecol. 51, 341-352. doi: 10.1016/j.femsec.2004. 09.012

Moodley, L., Middelburg, J. J., Boschker, H. T. S., Duineveld, G. C. A., Pel, R., Herman, P. M. J., et al. (2002). Bacteria and foraminifera: key players in a short-term deep-sea benthic response to phytodetritus. Mar. Ecol. Prog. Ser. 236, 23-29. doi: 10.3354/meps236023

Moodley, L., Middelburg, J. J., Soetaert, K., Boschker, H. T. S., Herman, P. M. J., and Heip, C. H. R. (2005). Similar rapid response to phytodetritus deposition in shallow and deep-sea sediments. J. Mar. Res. 63, 457-469. doi: 10.1357/ 0022240053693662

Morata, N., Michaud, E., and Włodarska-Kowalczuk, M. (2015). Impact of early food input on the Arctic benthos activities during the polar night. Polar Biol. 38, 99-114. doi: 10.1007/s00300-013-1414-5

Morata, N., Poulin, M., and Renaud, P. E. (2011). A multiple biomarker approach to tracking the fate of an ice algal bloom to the sea floor. Polar Biol. 34, 101-112. doi: 10.1007/s00300-010-0863-3

Morita, R. Y. (1982). Starvation-survival of heterotrophs in the marine environment. Adv. Microb. Ecol. 6, 171-198. doi: 10.1007/978-1-46158318-9_5

Niederlehner, B. R., and Cairns, J. (1994). Consistency and sensitivity of community level endpoints in microcosm tests. J. Aquat. Ecosyst. Health 3, 93-99. doi: 10.1007/BF00042939

Nogi, Y., Hosoya, S., Kato, C., and Horikoshi, K. (2004). Colwellia piezophila sp. nov., a novel piezophilic species from deep-sea sediments of the Japan Trench. Int. J. Syst. Evol. Microbiol. 54, 1627-1631. doi: 10.1099/ijs.0.03049-0

Ohta, H., Hattori, R., Ushiba, Y., Mitsui, H., Ito, M., Watanabe, H., et al. (2004). Sphingomonas oligophenolica sp. nov., a halo- and organo-sensitive oligotrophic bacterium from paddy soil that degrades phenolic acids at low concentrations. Int. J. Syst. Evol. Microbiol. 54, 2185-2190. doi: 10.1099/ijs.0.02959-0

Oksanen, J., Blanchet, F. G., Kindt, R., Legendre, P., Minchin, P. R., O’Hara, R. B., et al. (2015). Vegan: Communityecology. Available online at: http://CRAN.Rproject.org/package=vegan

O‘Toole, G., Kaplan, H. B., and Kolter, R. (2000). Biofilm formation asmicrobial development. Annu. Rev. Microbiol. 54, 49-79. doi: 10.1146/annurev.micro. 54.1 .49 
Parkes, R. J., Sellek, G., Webster, G., Martin, D., Anders, E., Weightman, A. J., et al. (2009). Culturable prokaryotic diversity of deep, gas hydrate sediments: first use of a continuous high-pressure, anaerobic, enrichment and isolation system for subseafloor sediments (DeepIsoBUG). Environ. Microbiol. 11, 3140-3153. doi: 10.1111/j.1462-2920.2009.02018.x

Parrilli, E., Ricciardelli, A., Casillo, A., Sannino, F., Papa, R., Tilotta, M., et al. (2016). Large-scale biofilm cultivation of Antarctic bacterium Pseudoalteromonas haloplanktis TAC125 for physiologic studies and drug discovery. Extremophiles 20, 227-234. doi: 10.1007/s00792-016-0813-2

Pati, A., Abt, B., Teshima, H., Nolan, M., Lapidus, A., Lucas, S., et al. (2011). Complete genome sequence of Cellulophaga lytica type strain (LIM-21T). Stand. Genomic Sci. 4, 221-232. doi: 10.4056/sigs.1774329

Pfannkuche, O. (1992). "Organic carbon flux through the benthic community in the temperate abyssal Northeast Atlantic," in Deep-Sea Food Chains and the Global Carbon Cycle, eds G. T. Rowe and V. Pariente (Dordrecht: Kluwer Academic Publishers), 183-198. doi: 10.1007/978-94-011-2452-2

Picard, A., and Daniel, I. (2013). Pressure as an environmental parameter for microbial life-a review. Biophys. Chem. 183, 30-41. doi: 10.1016/j.bpc.2013. 06.019

Pinheiro, J., Bates, D., DebRoy, S., Sarkar, D., Authors, E., Heisterkamp, S., et al. (2016). NLME: Linear and Nonlinear Mixed Effects Models. R-package, 1-336. Available at: http://CRAN.R-project.org/package=nlme

Proctor, L. M., and Fuhrman, J. A. (1990). Viral mortality of marine bacteria and cyanobacteria. Nature 343, 60-62. doi: 10.1038/343060a0

Pruesse, E., Peplies, J., and Glöckner, F. O. (2012). SINA: accurate high-throughput multiple sequence alignment of ribosomal RNA genes. Bioinformatics 28, $1823-$ 1829. doi: 10.1093/bioinformatics/bts252

Qin, J. G., Antignana, T. D., Zhang, W., and Franco, C. (2013). Discovery of antimicrobial activities of a marine diatom Thalassiosira rotula. Afr. J. Microbiol. Res. 7, 5687-5696. doi: 10.5897/AJMR12.2183

R Development Core Team (2014). R: A Language and Environment for Statistical Computing. R Foundation for Statistical Computing, Vienna, Austria. Available at: http://www.R-project.org/

Riley, M., Staley, J. T., Danchin, A., Wang, T. Z., Brettin, T. S., Hauser, L. J., et al. (2008). Genomics of an extreme psychrophile, Psychromonas ingrahamii. BMC Genomics 9:210. doi: 10.1186/1471-2164-9-210

Rowe, G. (1991). Total' sediment biomass and preliminary estimates of organic carbon residence time in deep-sea benthos. Mar. Ecol. Prog. Ser. 79, 99-114. doi: 10.3354/meps079099

Saha, M., Rempt, M., Gebser, B., Grueneberg, J., Pohnert, G., and Weinberger, F. (2012). Dimethylsulphopropionate (DMSP) and proline from the surface of the brown alga Fucus vesiculosus inhibit bacterial attachment. Biofouling 28, 593-604. doi: 10.1080/08927014.2012.698615

Schindler, D. W. (1987). Detecting ecosystem responses to anthropogenic stress. Can. J. Fish. Aquat. Sci. 44, 6-25.

Sokolova, M. N. (1994). Euphausiid "dead body rain" as a source of food for abyssal benthos. Deep Sea Res. Part I Oceanogr. Res. Pap. 41, 741-746. doi: 10.1016/0967-0637(94)90052-3

Soltwedel, T. (2015). The Expedition PS93.2 of the Research Vessel POLARSTERN to the Fram Strait in 2015. Reports on Polar and Marine Research (Bremerhaven: Alfred Wegener Institute for Polar and Marine Research). doi: 10.2312/BzPM_ 0693_2015

Soltwedel, T., Bauerfeind, E., Bergmann, M., Bracher, A., Budaeva, N., Busch, K., et al. (2015). Natural variability or anthropogenically-induced variation? Insights from 15 years of multidisciplinary observations at the arctic marine LTER site HAUSGARTEN. Ecol. Indic. 65, 89-102. doi: 10.1016/j.ecolind.2015. 10.001

Stecher, A., Neuhaus, S., Lange, B., Frickenhaus, S., Beszteri, B., Kroth, P. G., et al. (2015). rRNA and rDNA based assessment of sea ice protist biodiversity from the central Arctic Ocean. Eur. J. Phycol. 262, 1-16. doi: 10.1080/09670262.2015. 1077395

Sun, M.-Y., Carroll, M. L., Ambrose, W. G. Jr, Clough, L. M., Zou, L., and Lopez, G. R. (2007). Rapid consumption of phytoplankton and ice algae by Arctic softsediment benthic communities: evidence using natural and $13 \mathrm{C}$-labeled food materials. J. Mar. Res. 65, 561-588.

Teeling, H., Fuchs, B. M., Becher, D., Klockow, C., Gardebrecht, A., Bennke, C. M., et al. (2012). Substrate-controlled succession of marine bacterioplankton populations induced by a phytoplankton bloom. Science 336, 608-611. doi: $10.1126 /$ science. 1218344

Teeling, H., Fuchs, B. M., Bennke, C. M., Kru, K., Chafee, M., Kappelmann, L., et al. (2016). Recurring patterns in bacterioplankton dynamics during coastal spring algae blooms. Elife 5:e11888. doi: 10.7554/eLife.11888

Toffin, L., Webster, G., Weightman, A. J., Fry, J. C., and Prieur, D. (2004). Molecular monitoring of culturable bacteria from deep-sea sediment of the Nankai Trough, Leg 190 Ocean Drilling Program. FEMS Microbiol. Ecol. 48, 357-367. doi: 10.1016/j.femsec.2004.02.009

Turley, C. M., and Lochte, K. (1990). Microbial response to the input of fresh detritus to the deep-sea bed. Palaeogeogr. Palaeoclimatol. Palaeoecol. 89, 3-23. doi: 10.1016/0031-0182(90)90048-C

Vaz-Moreira, I., Nunes, O. C., and Manaia, C. M. (2011). Diversity and antibiotic resistance patterns of Sphingomonadaceae isolates from drinking water. Appl. Environ. Microbiol. 77, 5697-5706. doi: 10.1128/AEM.00579-11

Wakeham, S. G., and Lee, C. (1993). Production, transport, and alteration of particulate organic matter in the marine water column. Org. Geochem. 11, $145-169$.

Watson, S. P., Clements, M. O., and Foster, S. J. (1998). Characterization of the starvation-survival response of Staphylococcus aureus. J. Bacteriol. 180, 1750-1758.

Weiner, R. M., Taylor, L. E., Henrissat, B., Hauser, L., Land, M., Coutinho, P. M., et al. (2008). Complete genome sequence of the complex carbohydratedegrading marine bacterium, Saccharophagus degradans strain 2-40T. PLoS Genet. 4:e1000087. doi: 10.1371/journal.pgen.1000087

Winter, A., Henderiks, J., Beaufort, L., Rickaby, R. E. M., and Brown, C. W. (2014). Poleward expansion of the coccolithophore Emiliania huxleyi. J. Plankton Res. 36, 316-325. doi: 10.1093/plankt/fbt110

Witte, U., Aberle, N., Sand, M., and Wenzhöfer, F. (2003a). Rapid response of a deep-sea benthic community to POM enrichment: an in-situ experimental study. Mar. Ecol. 251, 27-36. doi: 10.3354/meps251027

Witte, U., Wenzhöfer, F., Sommer, S., Boetius, A., Heinz, P., Aberle, N., et al. (2003b). In situ experimental evidence of the fate of a phytodetritus pulse at the abyssal sea floor. Nature 424, 763-766. doi: 10.1038/nature 01799

Wolf, D. C., and Skipper, H. D. (1994). "Soil sterilization," in Methods of Soil Analysis. Part 2: Microbiological and Biochemical Properties, eds R. W. Weaver, S. Angle, P. Bottomley, D. Bezdicek, S. Smith, A. Tabatabai, et al. (Madison, WI: Soil Science Society of America, Inc.), 41-51.

Xing, P., Hahnke, R. L., Unfried, F., Markert, S., Huang, S., Barbeyron, T., et al. (2015). Niches of two polysaccharide-degrading Polaribacter isolates from the North Sea during a spring diatom bloom. ISME J. 9, 1410-1422. doi: 10.1038/ ismej.2014.225

Yabuuchi, E., and Kosako, Y. (2005). “Order IV. Sphingomonadales ord. nov," in Bergey's Manual of Systematic Bacteriology, Part C, Vol. 2, 2nd Edn, eds D. J. Brenner, N. R. Krieg, J. T. Staley, and G. M. Garrity (New York: Springer), 230-233.

Yanagibayashi, M., Nogi, Y., Li, L., and Kato, C. (1999). Changes in microbial community in Japan Trench sediment from a depth of $6292 \mathrm{~m}$ during cultivation without decompression. FEMS Microbiol. Lett. 170, 271-279.

Yayanos, A. A. (1986). Evolutional and ecological implications of the properties of deep-sea barophilic bacteria. Proc. Natl. Acad. Sci. U.S.A. 83, 9542-9546. doi: $10.1073 /$ pnas.83.24.9542

Zhang, J., Kobert, K., Flouri, T., and Stamatakis, A. (2014). PEAR: a fast and accurate Illumina Paired-End reAd mergeR. Bioinformatics 30, 614-620. doi: 10.1093/bioinformatics/btt593

Zhao, J. S., Deng, Y., Manno, D., and Hawari, J. (2010). Shewanella spp. genomic evolution for a cold marine lifestyle and in-situ explosive biodegradation. PLoS ONE 5:e9109. doi: 10.1371/journal.pone.0009109

Zhao, J. S., Manno, D., Beaulieu, C., Paquet, L., and Hawari, J. (2005). Shewanella sediminis sp. nov., a novel $\mathrm{Na}+$ - requiring and hexahydro-1,3,5-trinitro-1,3,5triazine-degrading bacterium from marine sediment. Int. J. Syst. Evol. Microbiol. 55, 1511-1520. doi: 10.1099/ijs.0.63604-0

Zinger, L., Amaral-Zettler, L. A., Fuhrman, J. A., Horner-Devine, M. C., Huse, S. M., Welch, D. B. M., et al. (2011). Global patterns of bacterial beta-diversity in seafloor and seawater ecosystems. PLoS ONE 6:e24570. doi: 10.1371/journal. pone. 0024570 
Conflict of Interest Statement: The authors declare that the research was conducted in the absence of any commercial or financial relationships that could be construed as a potential conflict of interest.

The reviewer AS and handling Editor declared their shared affiliation and the handling Editor states that the process nevertheless met the standards of a fair and objective review.
Copyright (ㄷ 2017 Hoffmann, Hassenrück, Salman-Carvalho, Holtappels and Bienhold. This is an open-access article distributed under the terms of the Creative Commons Attribution License (CC BY). The use, distribution or reproduction in other forums is permitted, provided the original author(s) or licensor are credited and that the original publication in this journal is cited, in accordance with accepted academic practice. No use, distribution or reproduction is permitted which does not comply with these terms. 